\title{
Synthesis of 2-Vinylindole-3-Acetic Acid Derivatives via Cyanide-Catalyzed Imino-Stetter Reaction
}

\author{
Hong-Ahn Seo and Cheol-Hong Cheon* \\ Department of Chemistry, Korea University, 145 Anam-ro, Seungbuk-gu, Seoul 02841, Republic of \\ Korea
}




\section{Spectroscopic data}

1. NMR Spectra of 1aa

a) ${ }^{1}$ H NMR Spectrum of $\mathbf{1 a a}$

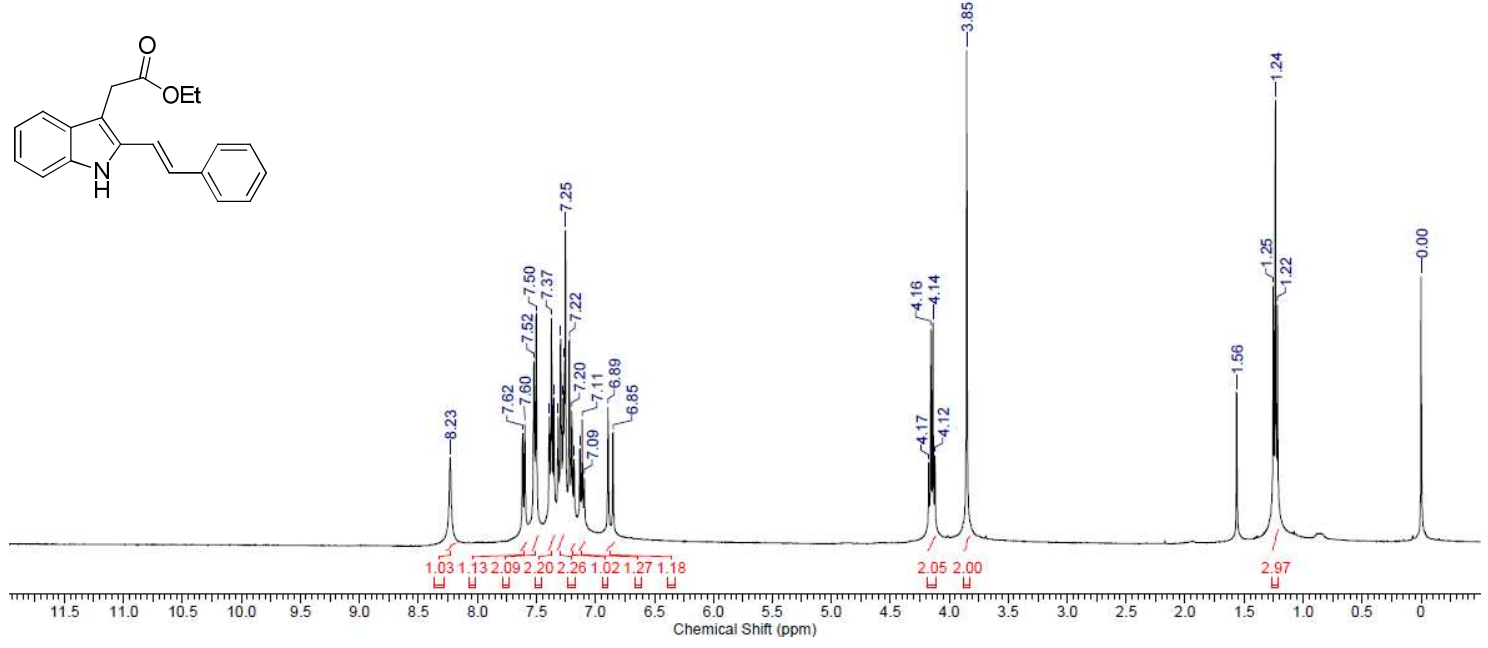

b) ${ }^{13} \mathrm{C}\left\{{ }^{1} \mathrm{H}\right\}$ NMR Spectrum of $\mathbf{1 a a}$

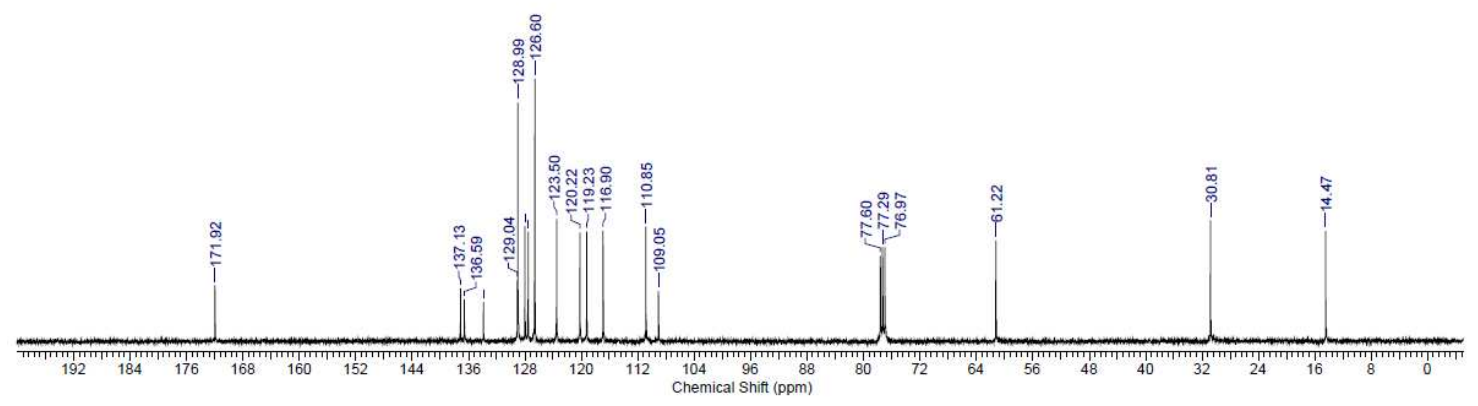


2. NMR Spectra of $\mathbf{1 a b}$

a) ${ }^{1}$ H NMR Spectrum of $\mathbf{1 a b}$

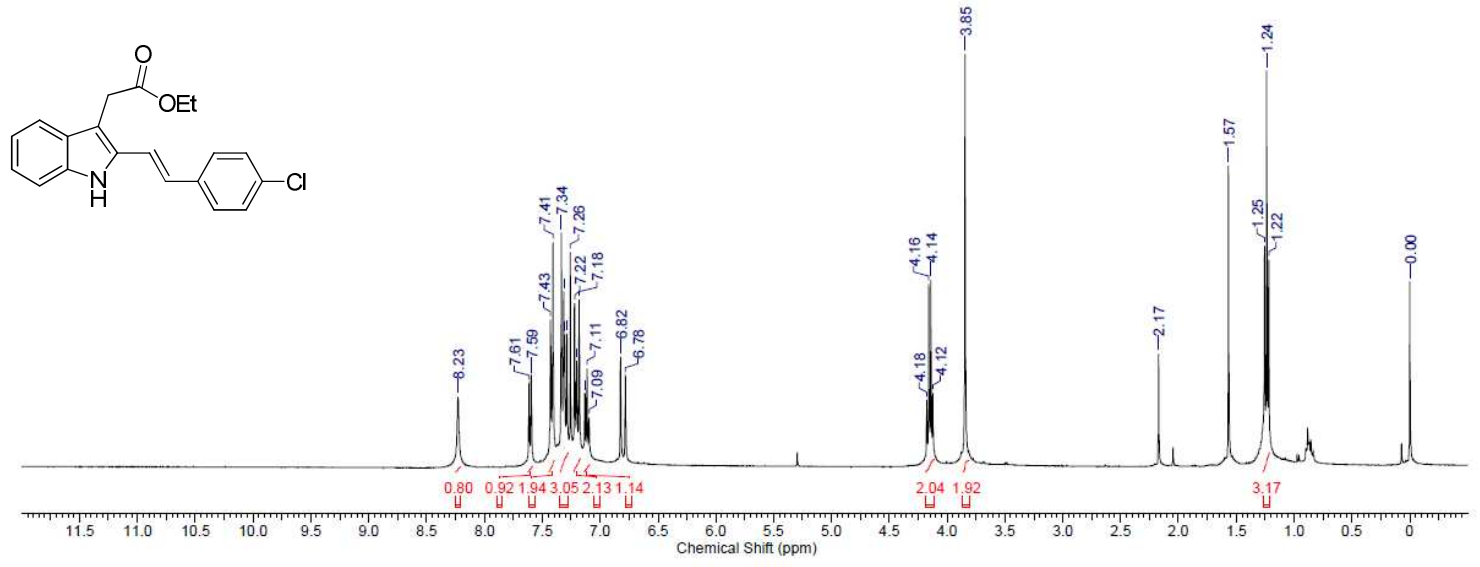

b) ${ }^{13} \mathrm{C}\left\{{ }^{1} \mathrm{H}\right\}$ NMR Spectrum of $\mathbf{1 a b}$

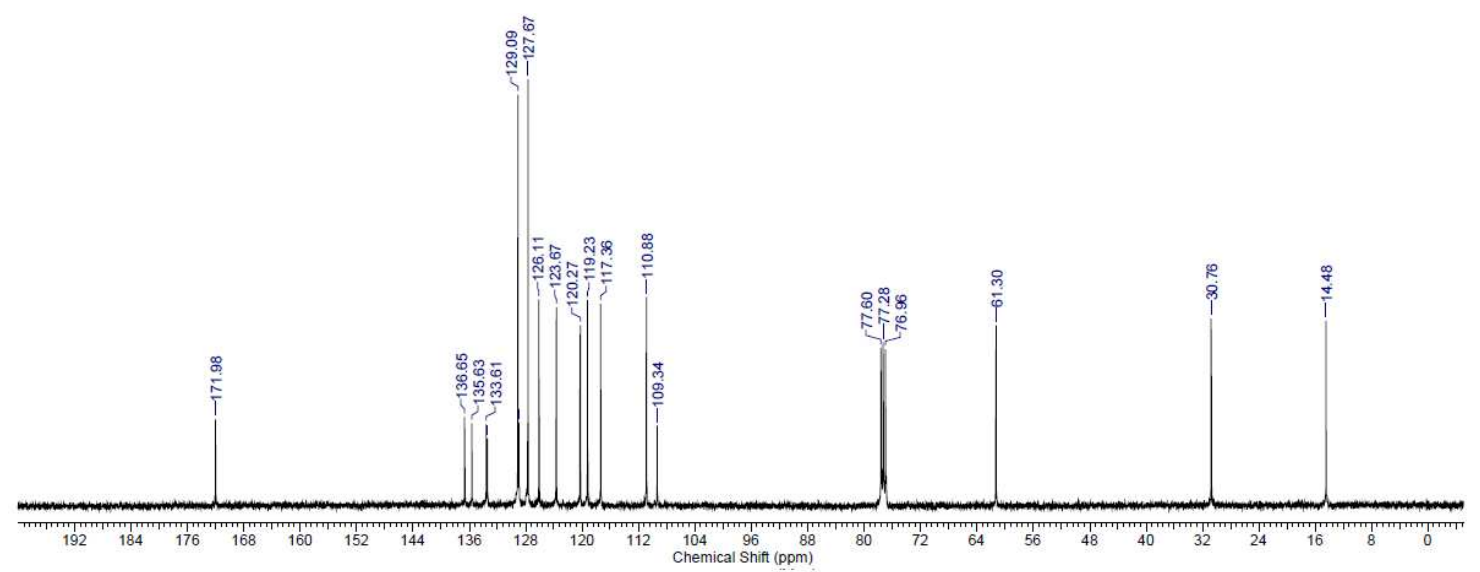


3. NMR Spectra of $\mathbf{1 a c}$

a) ${ }^{1} \mathrm{H}$ NMR Spectrum of $\mathbf{1 a c}$

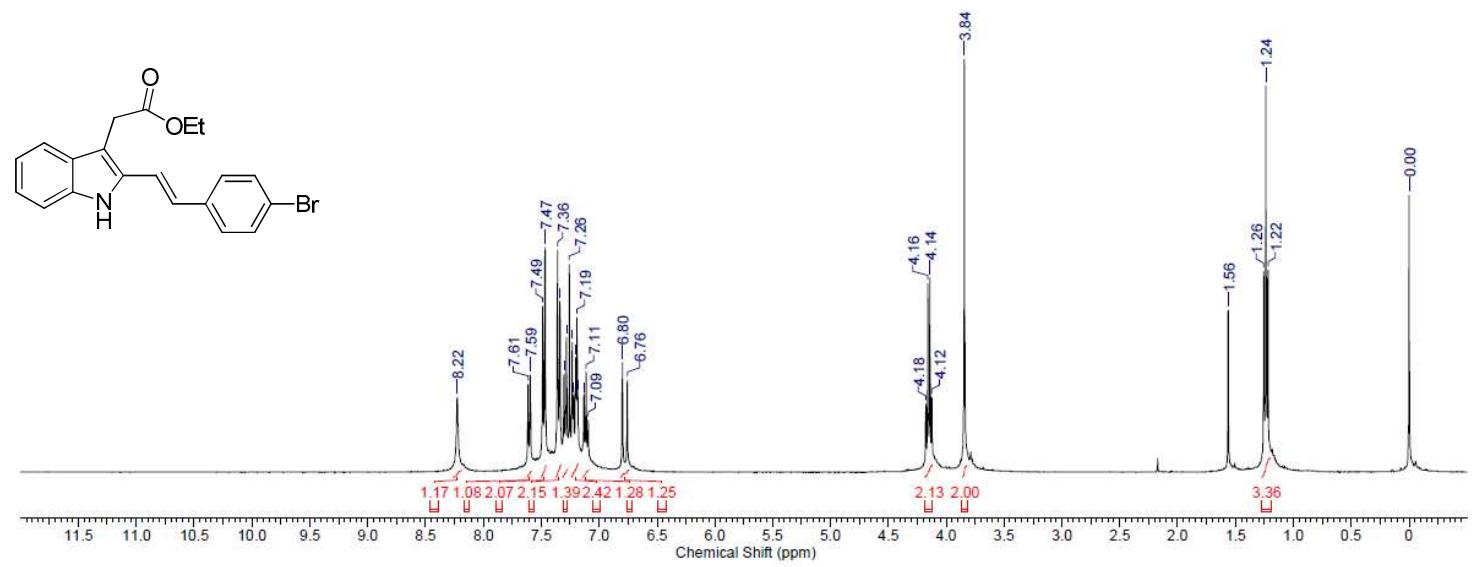

b) ${ }^{13} \mathrm{C}\left\{{ }^{1} \mathrm{H}\right\}$ NMR Spectrum of $\mathbf{1 a c}$

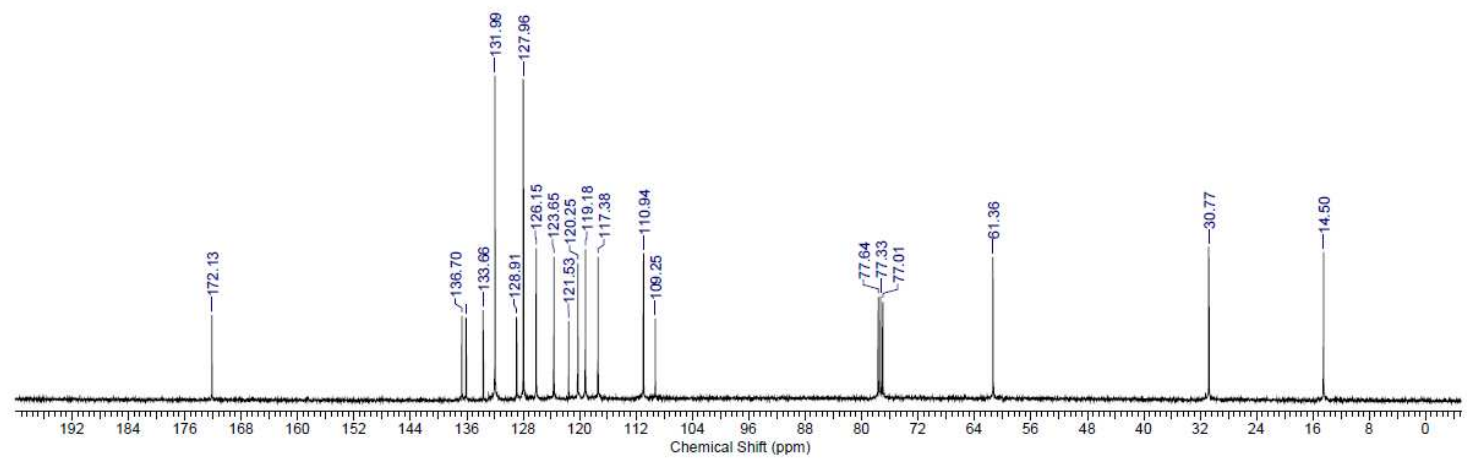


4. NMR Spectra of $\mathbf{1 a d}$

a) ${ }^{1}$ H NMR Spectrum of $\mathbf{1 a d}$
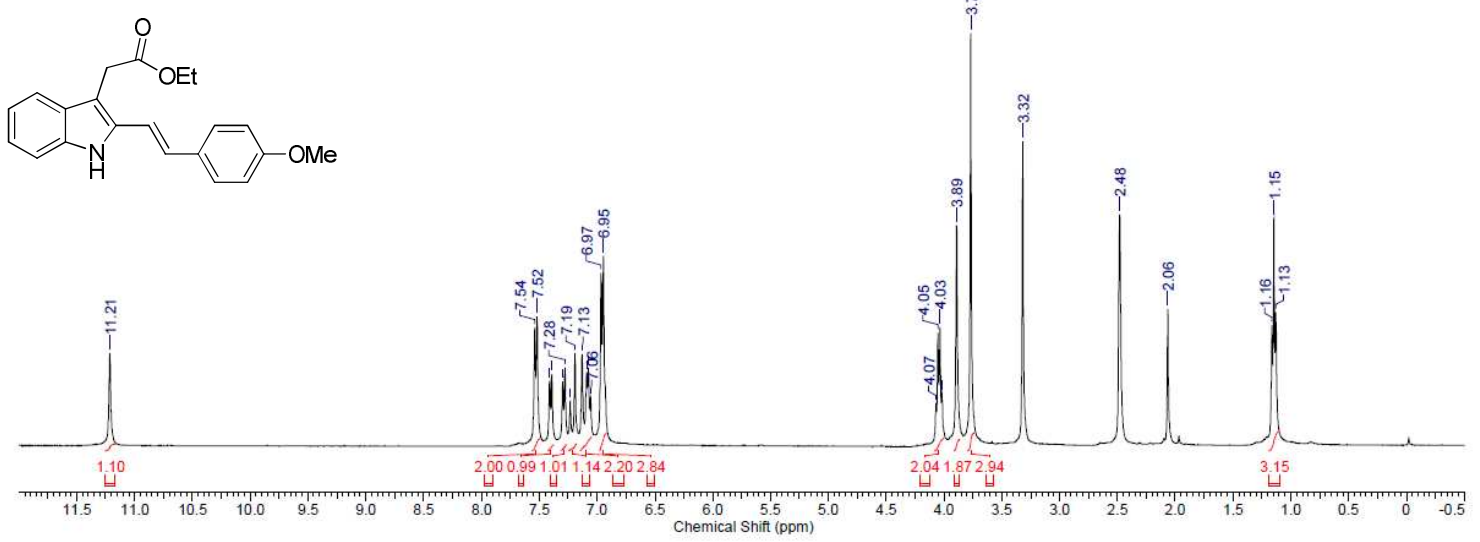

b) ${ }^{13} \mathrm{C}\left\{{ }^{1} \mathrm{H}\right\}$ NMR Spectrum of $\mathbf{1 a d}$

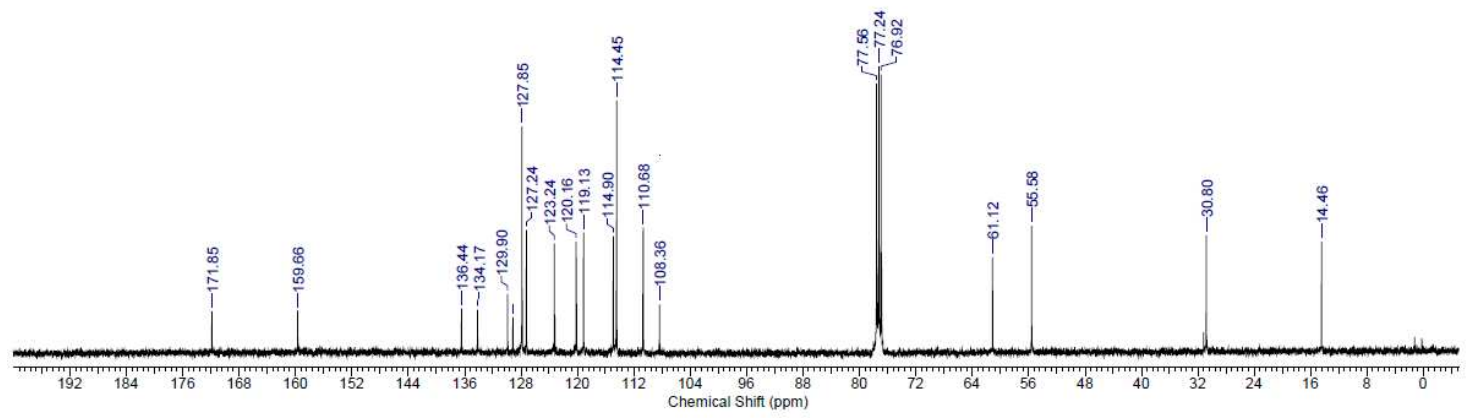


5. NMR Spectra of $\mathbf{1 a e}$

a) ${ }^{1}$ H NMR Spectrum of $\mathbf{1 a e}$

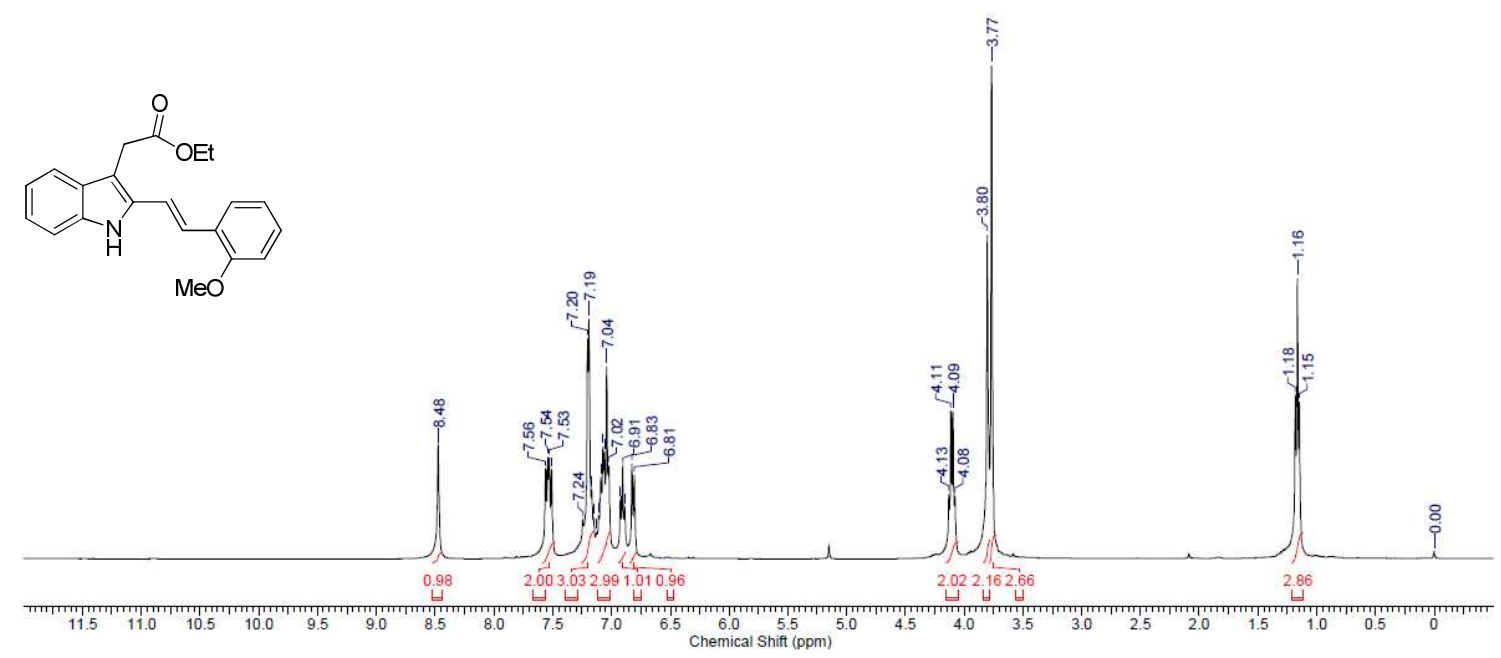

b) ${ }^{13} \mathrm{C}\left\{{ }^{1} \mathrm{H}\right\}$ NMR Spectrum of $\mathbf{1 a e}$

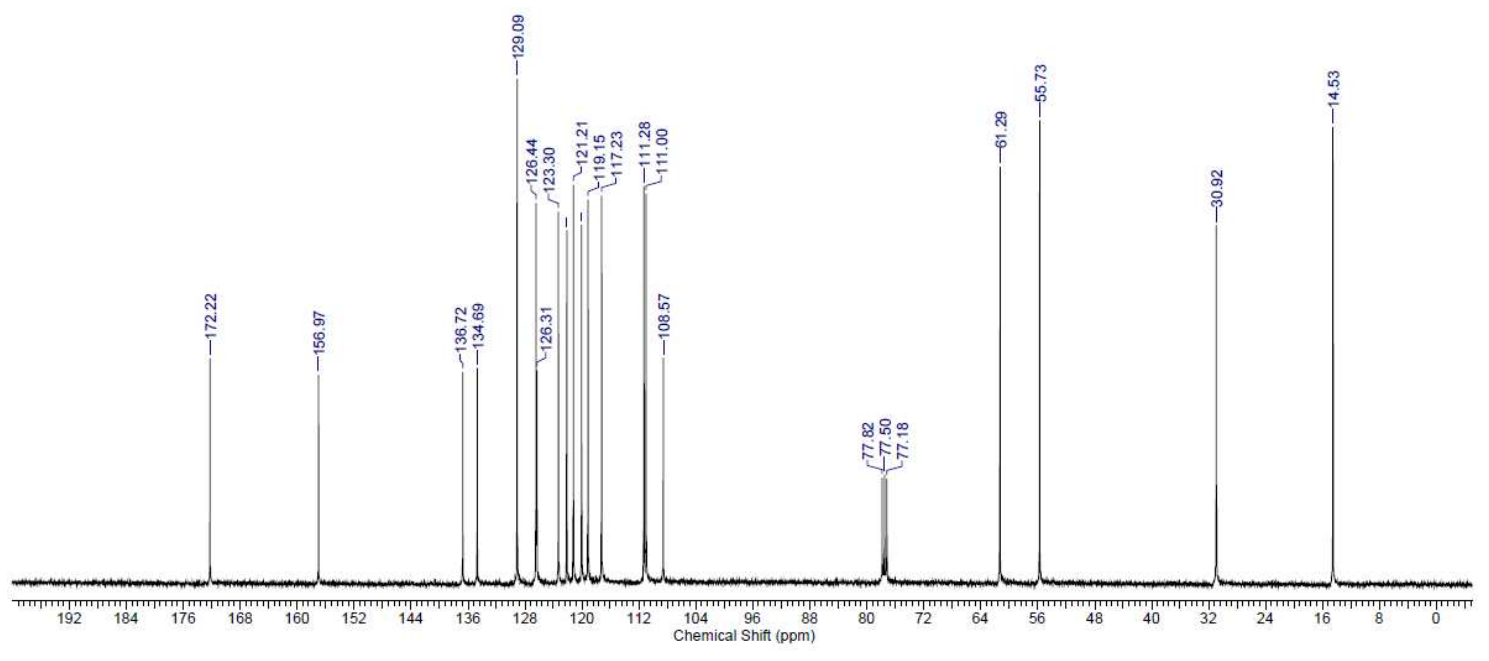


6. NMR Spectra of $\mathbf{1 a f}$

a) ${ }^{1} \mathrm{H}$ NMR Spectrum of $\mathbf{1 a f}$

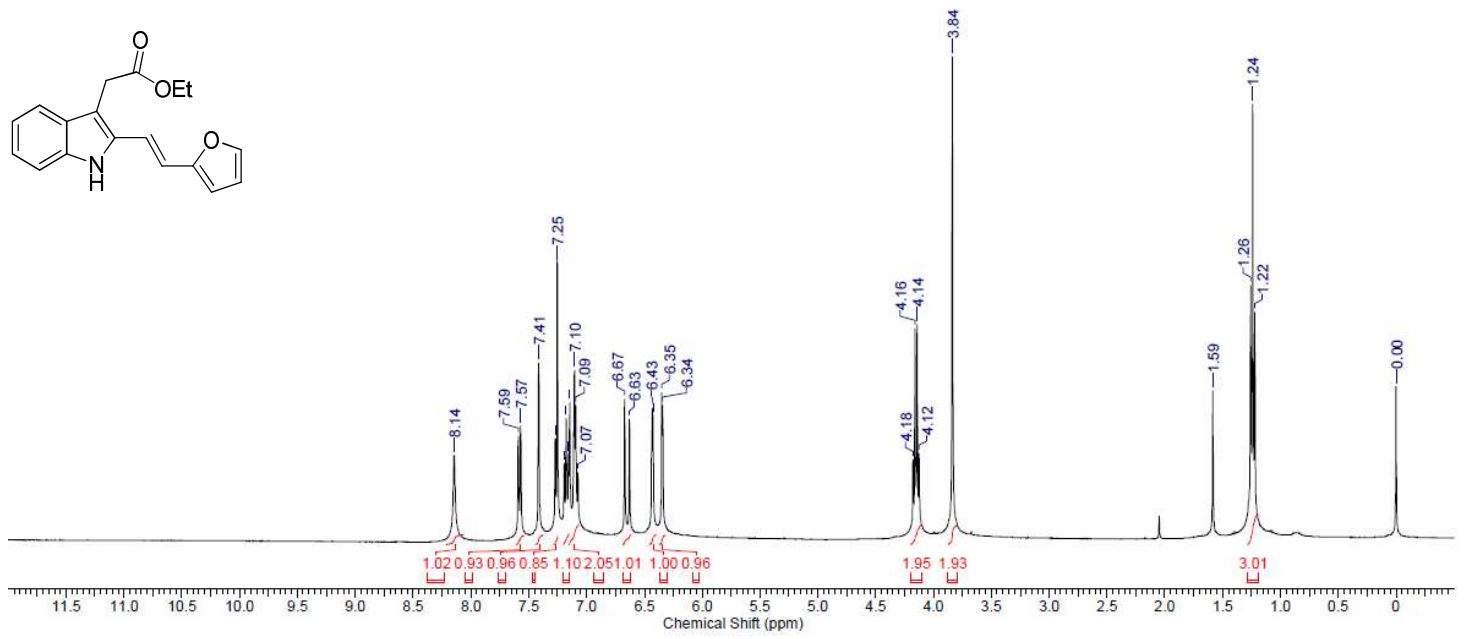

b) ${ }^{13} \mathrm{C}\left\{{ }^{1} \mathrm{H}\right\}$ NMR Spectrum of $\mathbf{1 a f}$

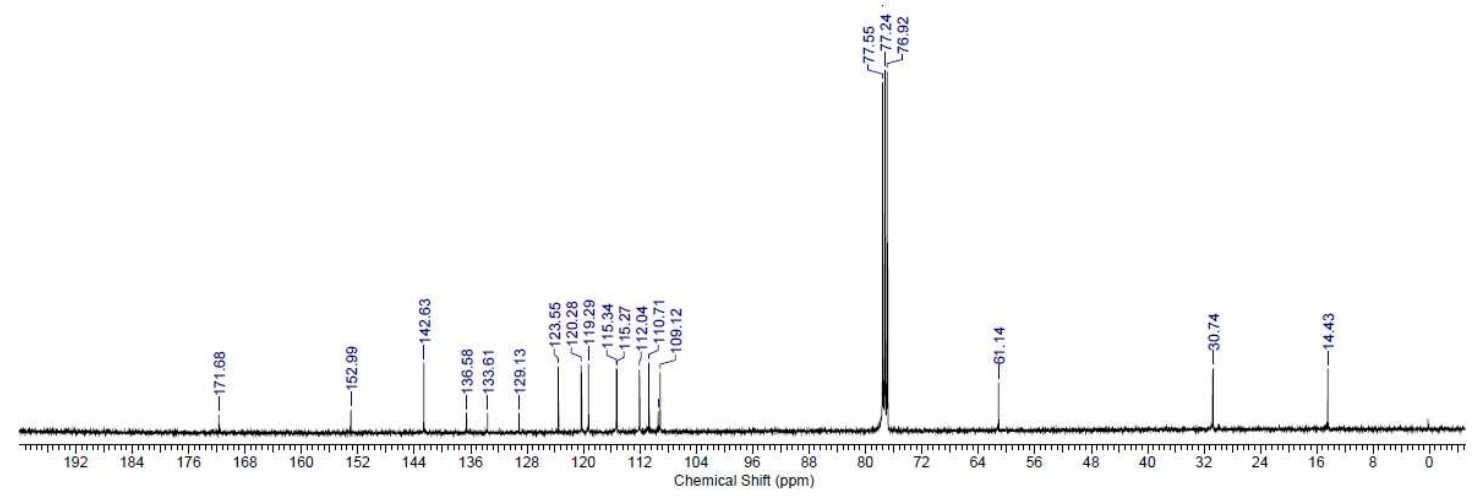


7. NMR Spectra of $\mathbf{1 a g}$

a) ${ }^{1} \mathrm{H}$ NMR Spectrum of $\mathbf{1 a g}$

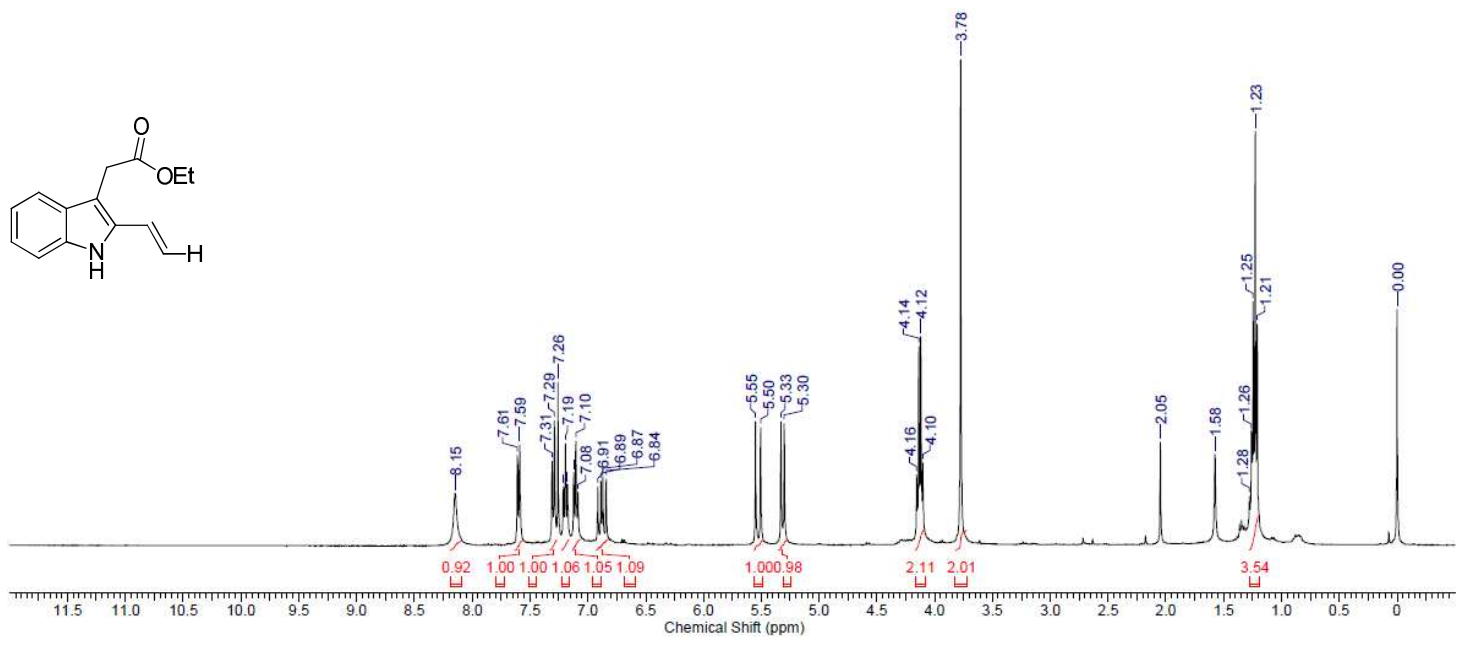

b) ${ }^{13} \mathrm{C}\left\{{ }^{1} \mathrm{H}\right\}$ NMR Spectrum of $\mathbf{1 a g}$

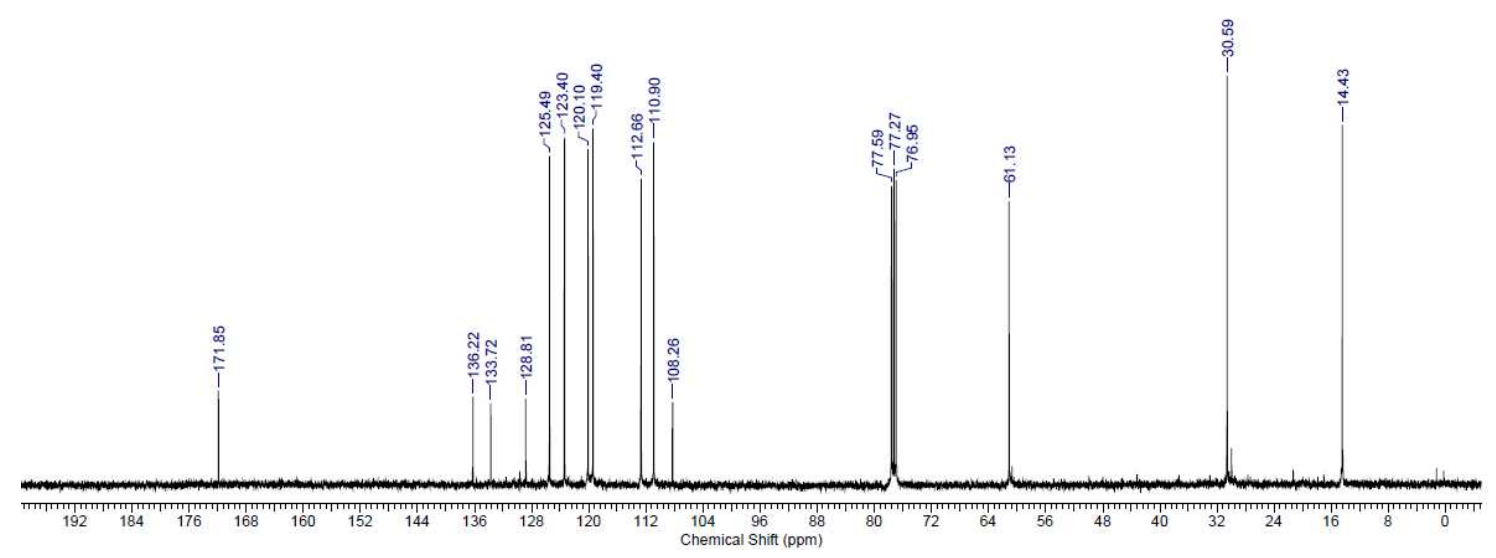




\section{NMR Spectra of $\mathbf{1 a h}$}

a) ${ }^{1} \mathrm{H}$ NMR Spectrum of $\mathbf{1 a h}$

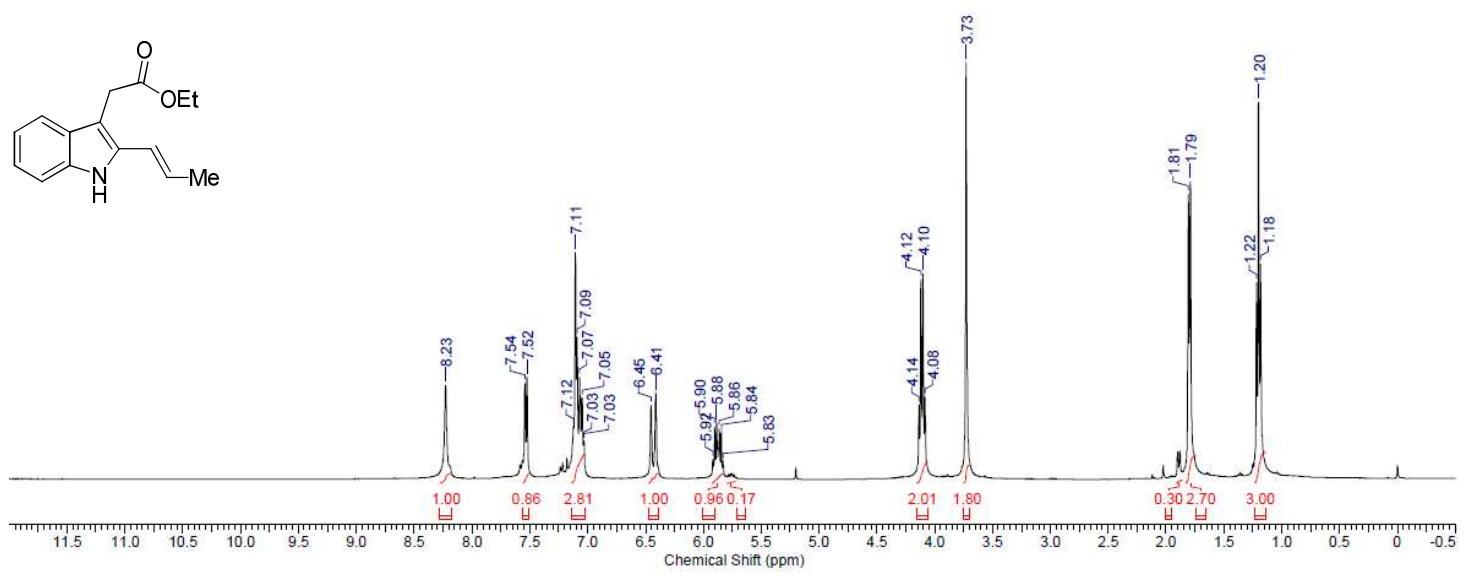

b) ${ }^{13} \mathrm{C}\left\{{ }^{1} \mathrm{H}\right\}$ NMR Spectrum of $\mathbf{1 a h}$

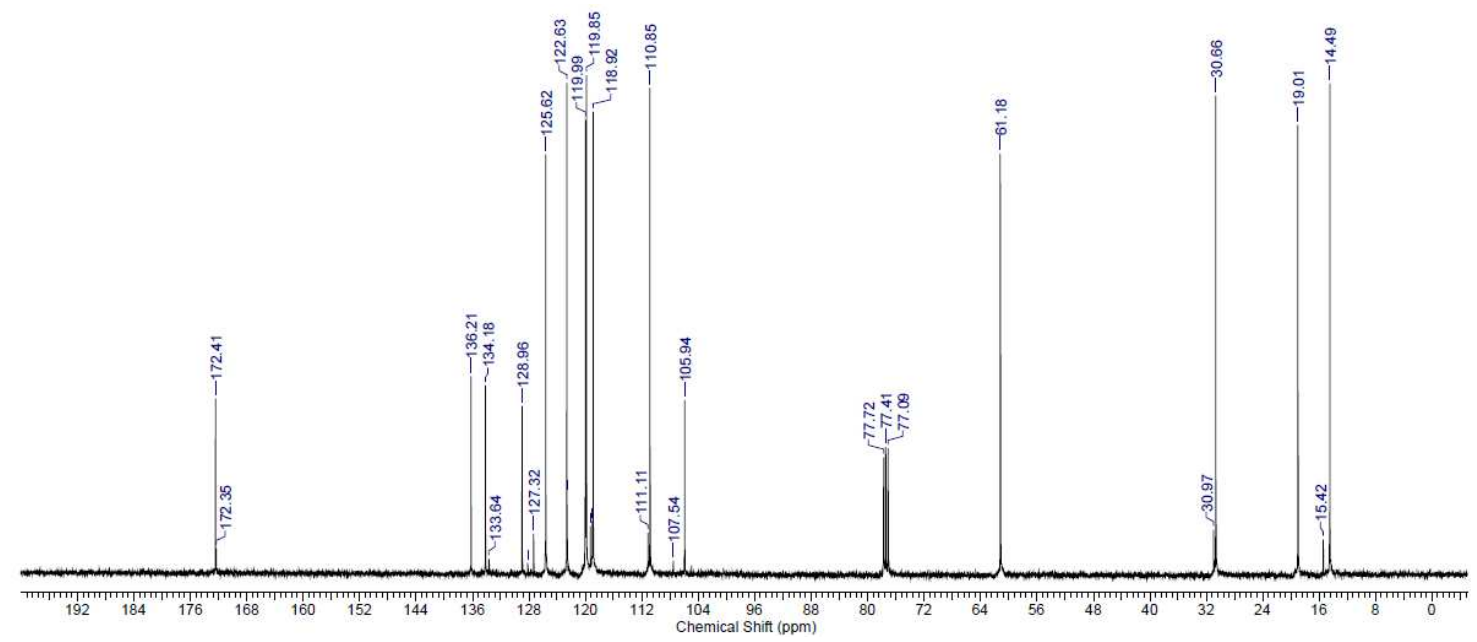


9. NMR Spectra of 1ai

a) ${ }^{1} \mathrm{H}$ NMR Spectrum of $\mathbf{1 a i}$

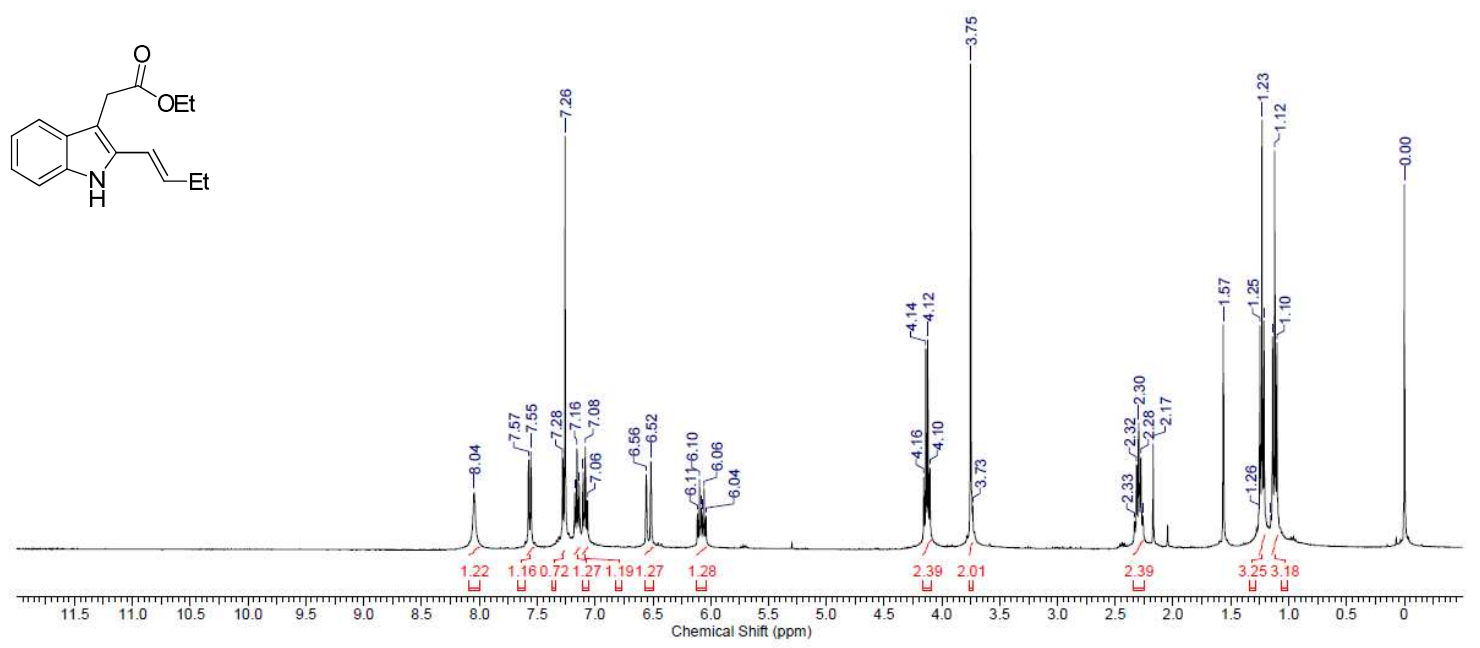

b) ${ }^{13} \mathrm{C}\left\{{ }^{1} \mathrm{H}\right\}$ NMR Spectrum of $\mathbf{1 a i}$

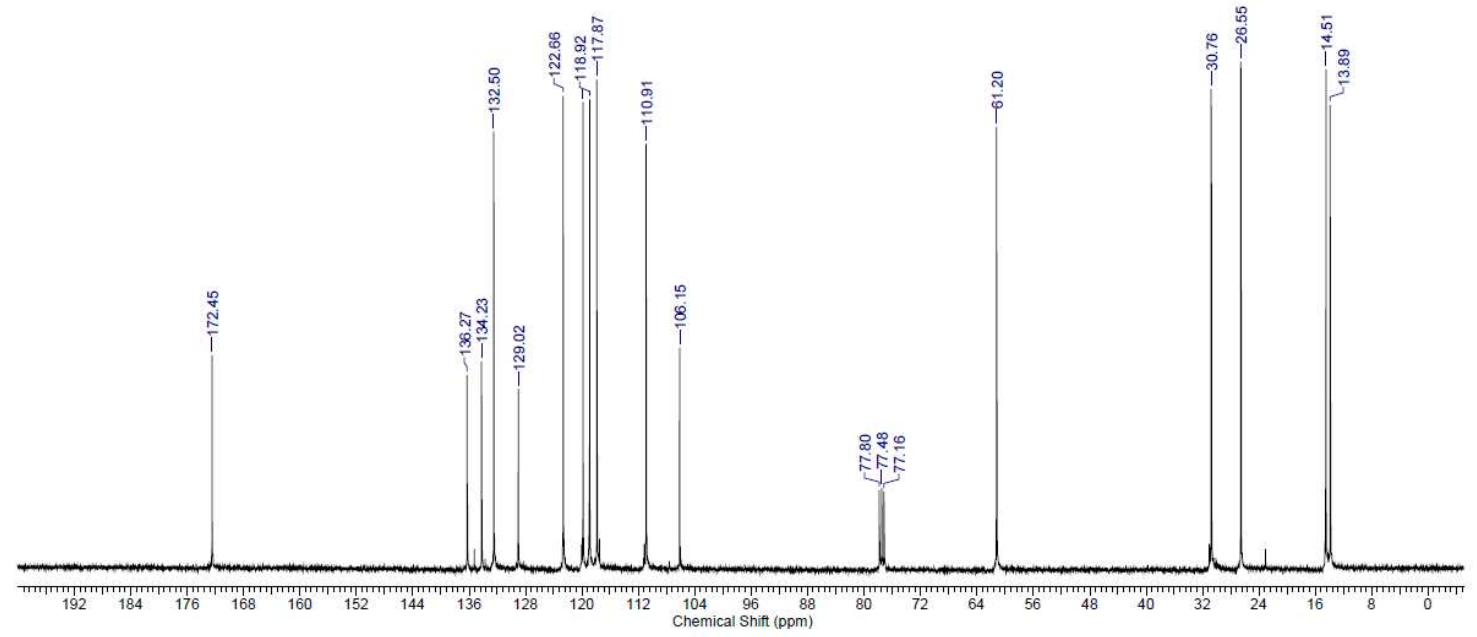


10. NMR Spectra of $\mathbf{1 a j}$

a) ${ }^{1} \mathrm{H}$ NMR Spectrum of $\mathbf{1 a j}$

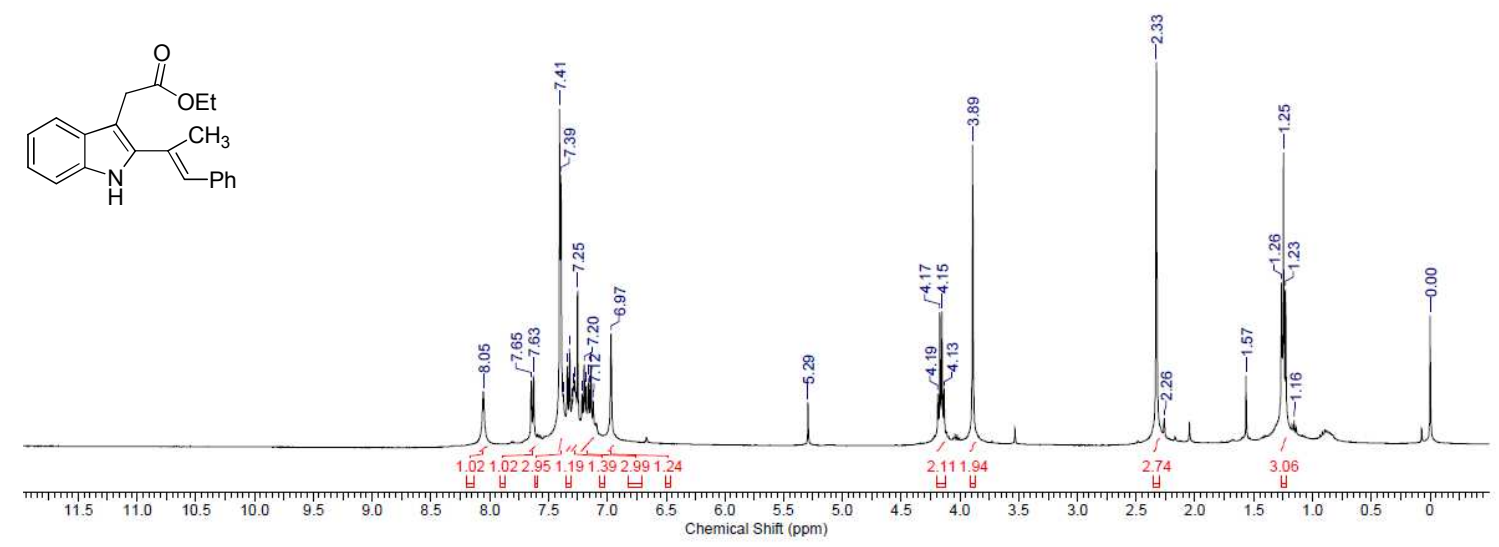

b) ${ }^{13} \mathrm{C}\left\{{ }^{1} \mathrm{H}\right\}$ NMR Spectrum of $\mathbf{1 a j}$

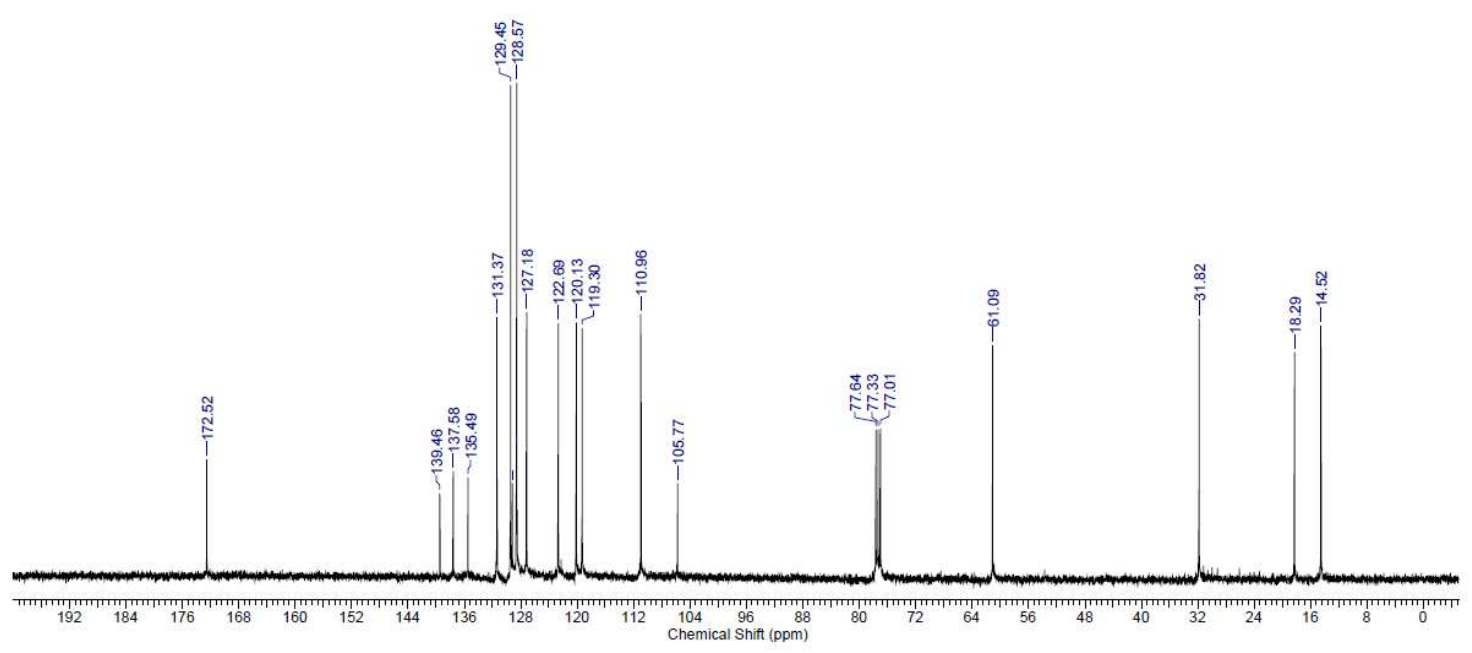


11. NMR Spectra of $\mathbf{1 b a}$

a) ${ }^{1} \mathrm{H}$ NMR Spectrum of $\mathbf{1} \mathbf{b a}$<smiles>COC(=O)Cc1c(/C=C/c2ccccc2)[nH]c2ccc(Br)cc12</smiles>

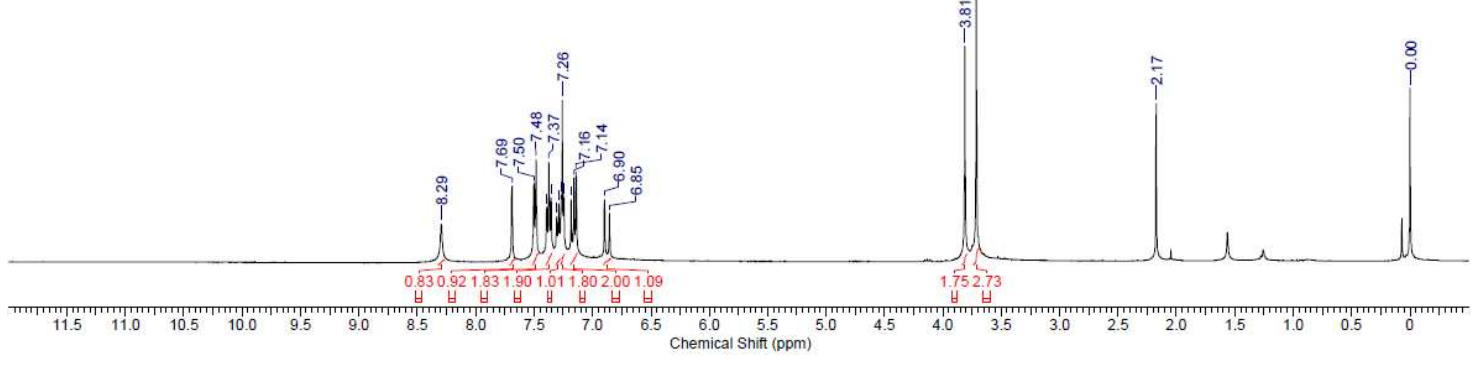

b) ${ }^{13} \mathrm{C}\left\{{ }^{1} \mathrm{H}\right\}$ NMR Spectrum of $\mathbf{1 b a}$

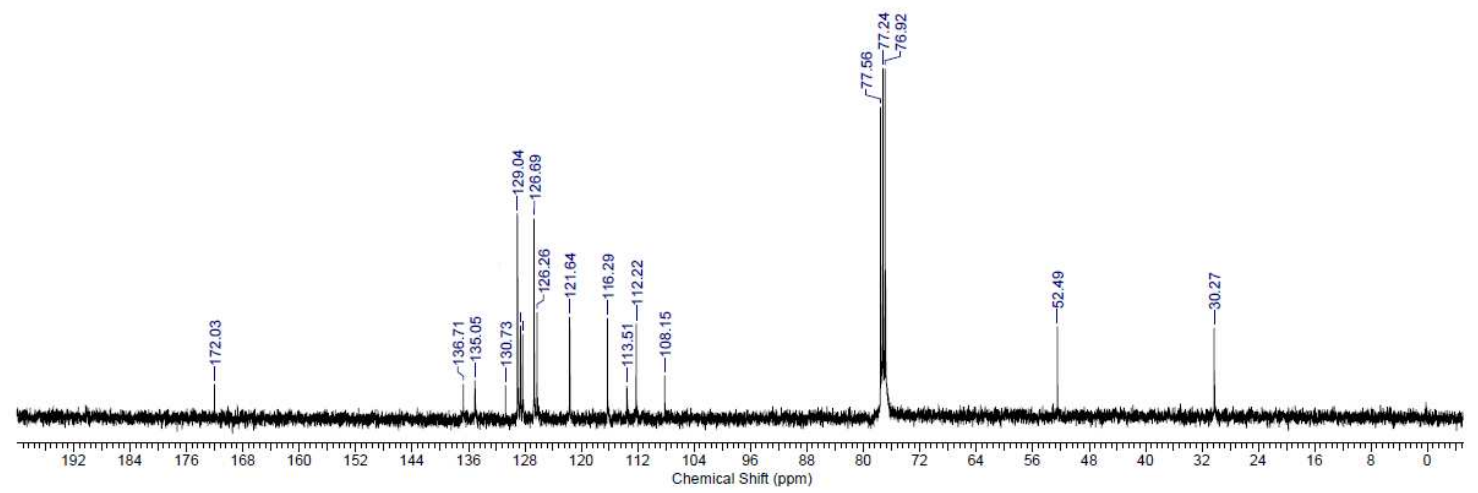


12. NMR Spectra of $\mathbf{1} \mathbf{c a}$

a) ${ }^{1} \mathrm{H}$ NMR Spectrum of $\mathbf{1} \mathbf{c a}$

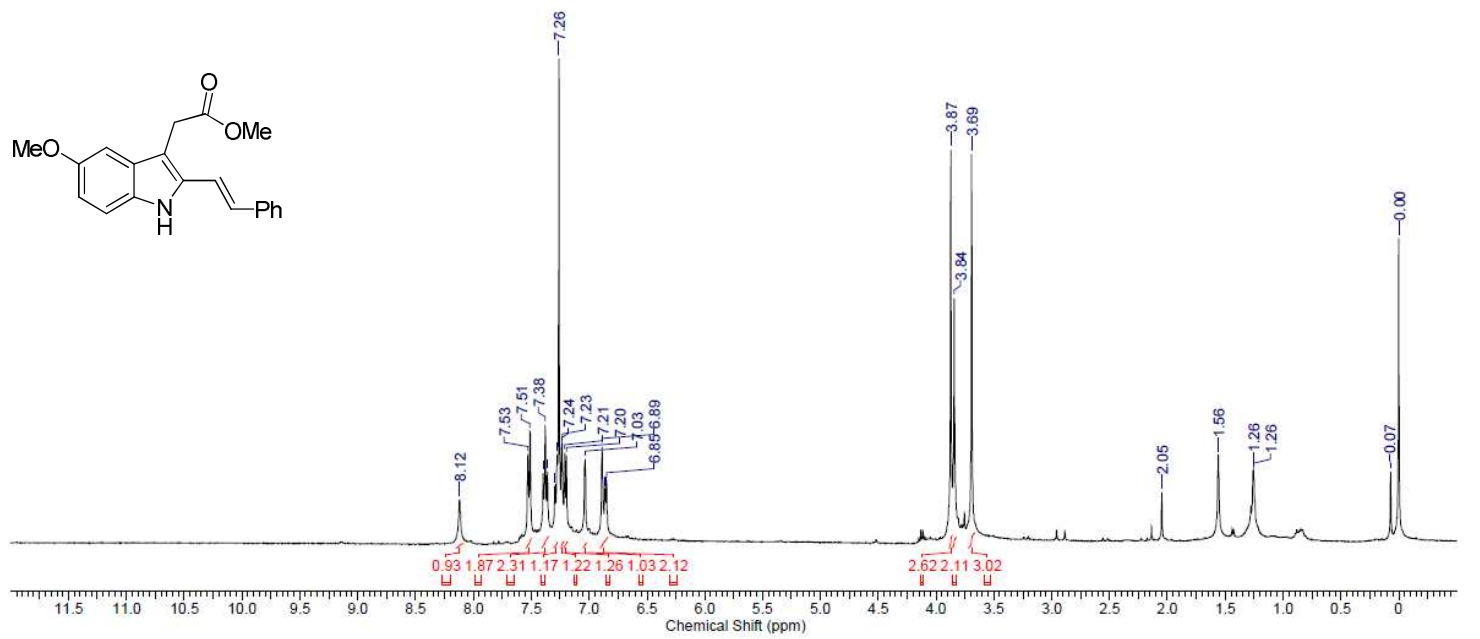

b) ${ }^{13} \mathrm{C}\left\{{ }^{1} \mathrm{H}\right\}$ NMR Spectrum of $\mathbf{1 c a}$

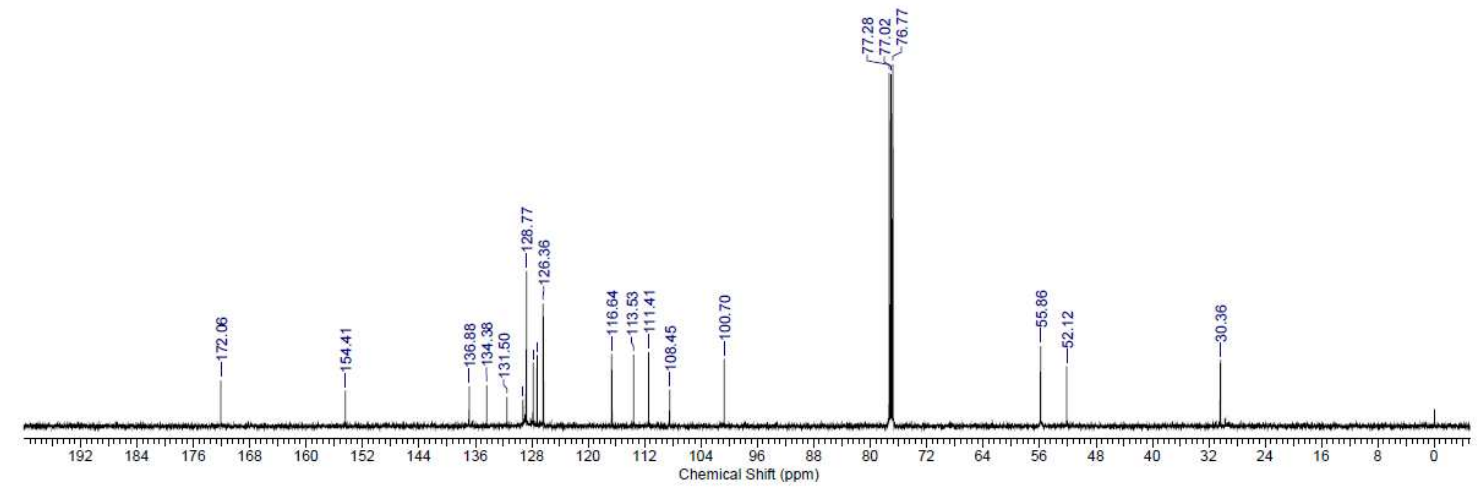


13. NMR Spectra of $\mathbf{1 d a}$

a) ${ }^{1} \mathrm{H}$ NMR Spectrum of $\mathbf{1 d a}$

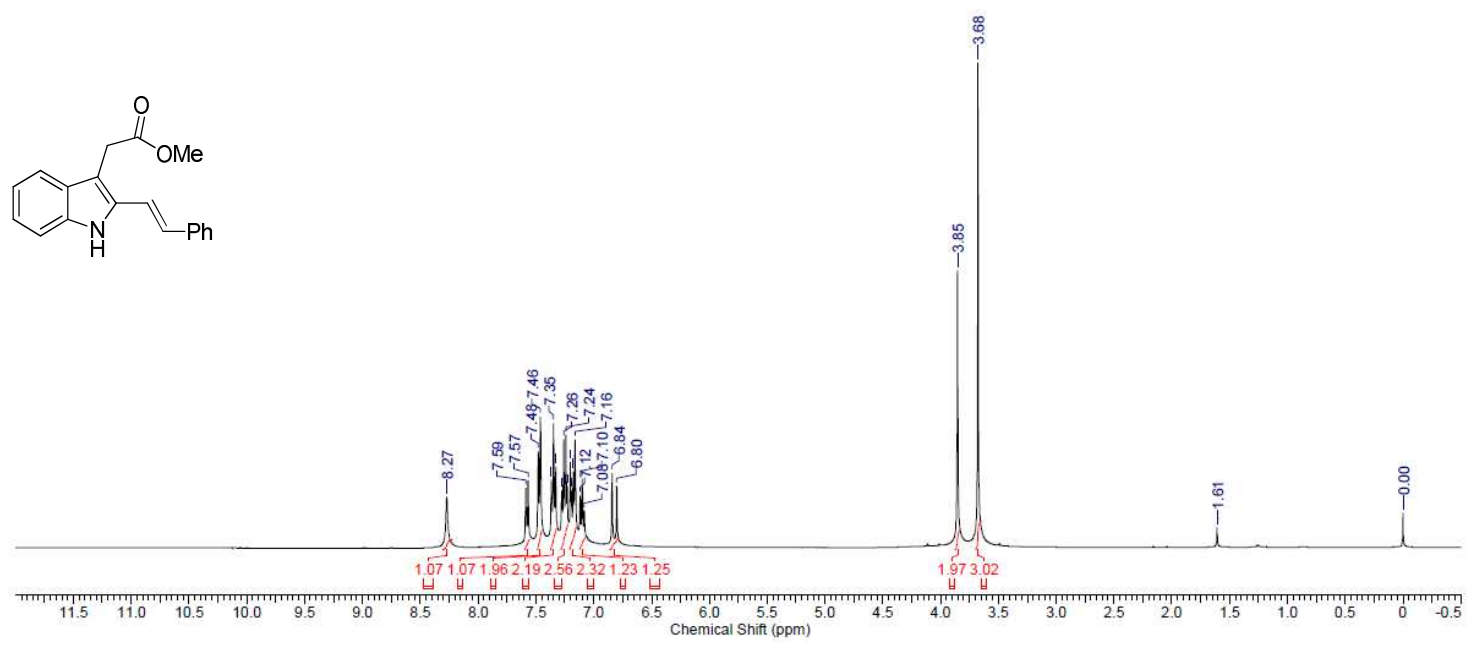

b) ${ }^{13} \mathrm{C}\left\{{ }^{1} \mathrm{H}\right\}$ NMR Spectrum of $\mathbf{1 d a}$

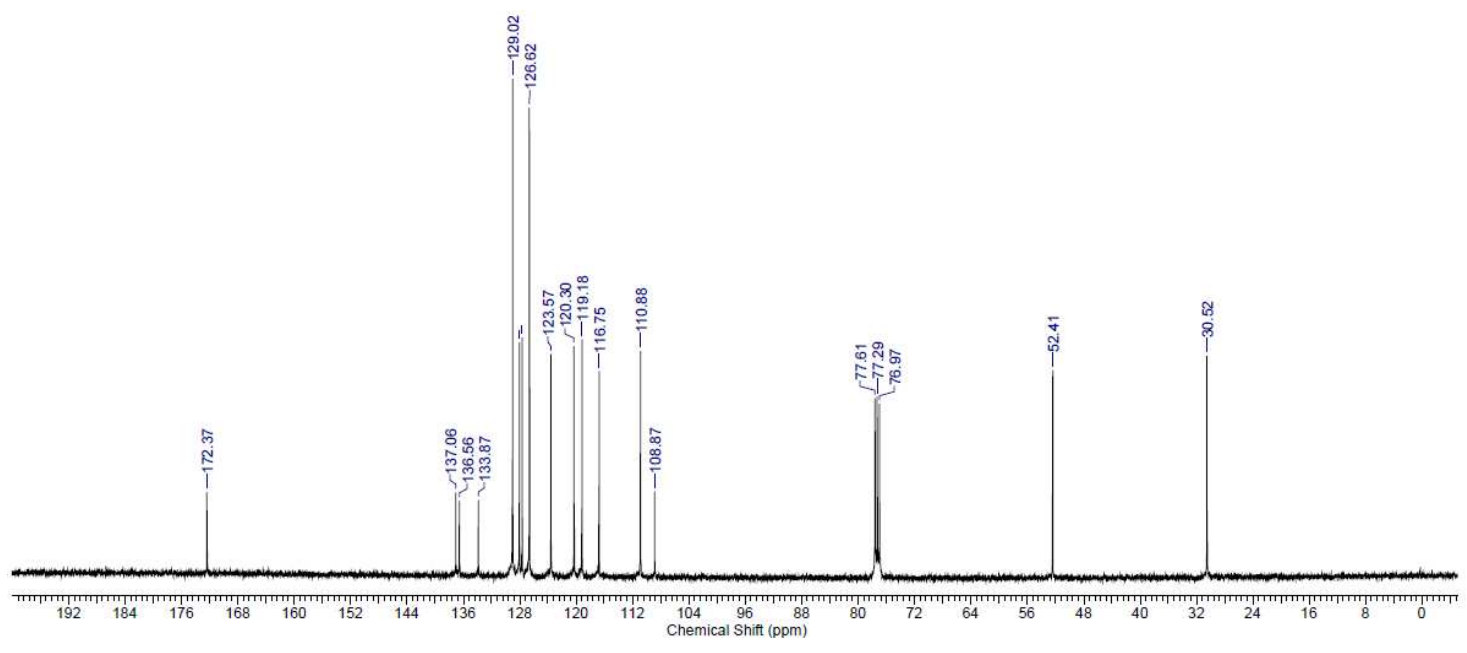


14. NMR Spectra of 1ea

a) ${ }^{1} \mathrm{H}$ NMR Spectrum of $\mathbf{1 e a}$

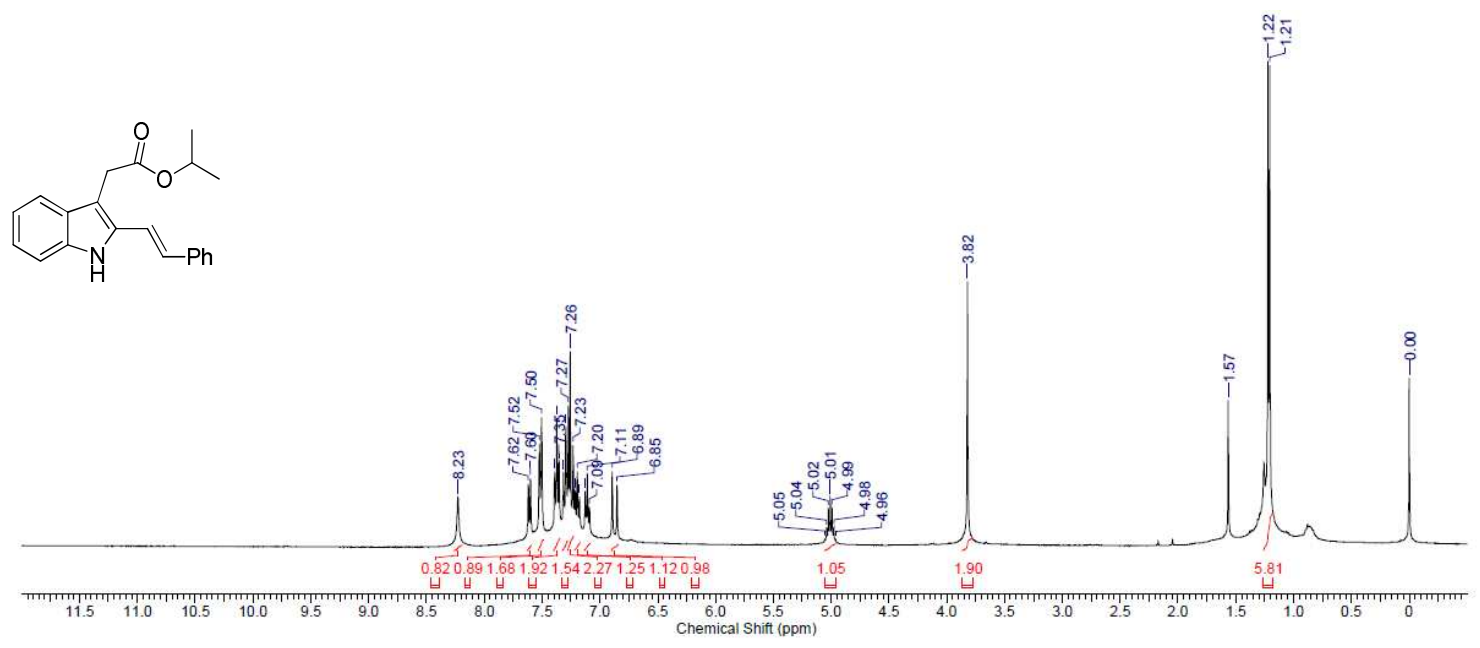

b) ${ }^{13} \mathrm{C}\left\{{ }^{1} \mathrm{H}\right\}$ NMR Spectrum of 1ea

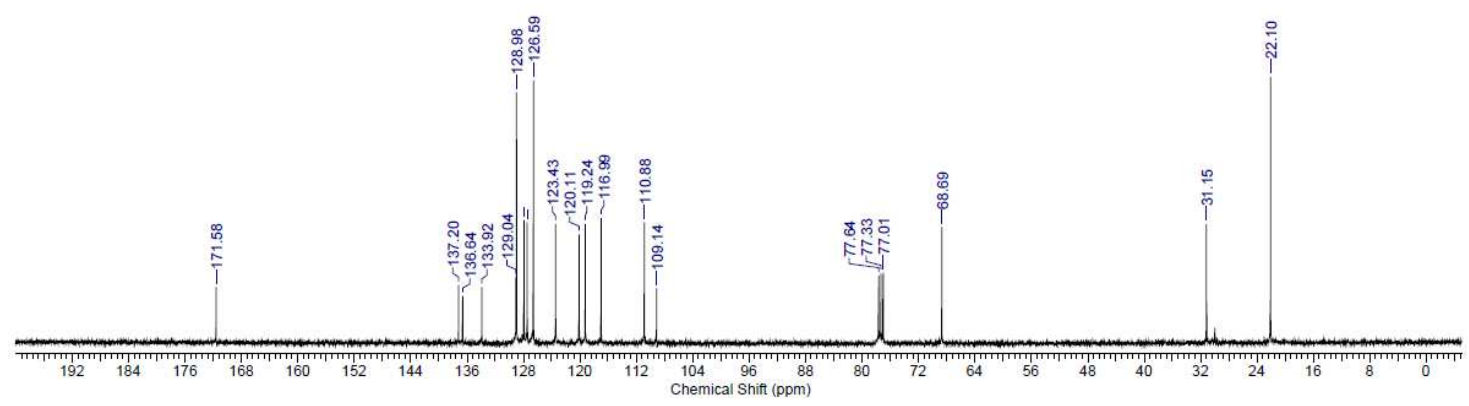


15. NMR Spectra of $\mathbf{1 f a}$

a) ${ }^{1} \mathrm{H}$ NMR Spectrum of $\mathbf{1} \mathbf{f a}$

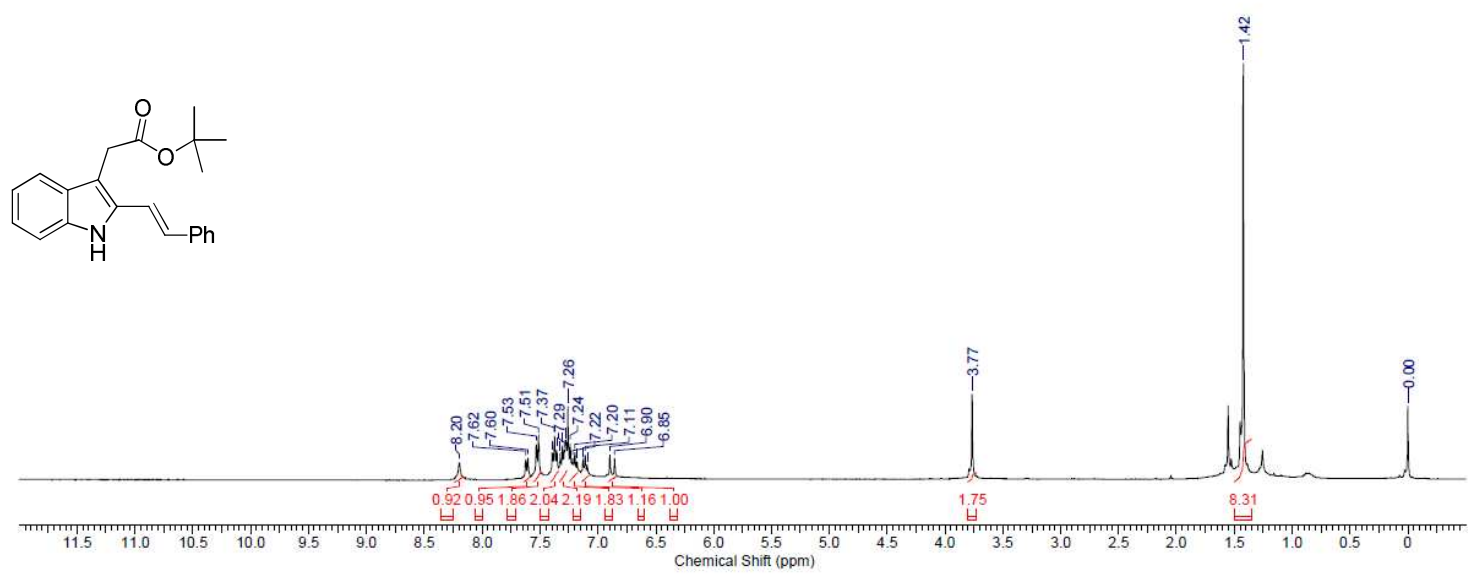

b) ${ }^{13} \mathrm{C}\left\{{ }^{1} \mathrm{H}\right\}$ NMR Spectrum of $\mathbf{1 f a}$

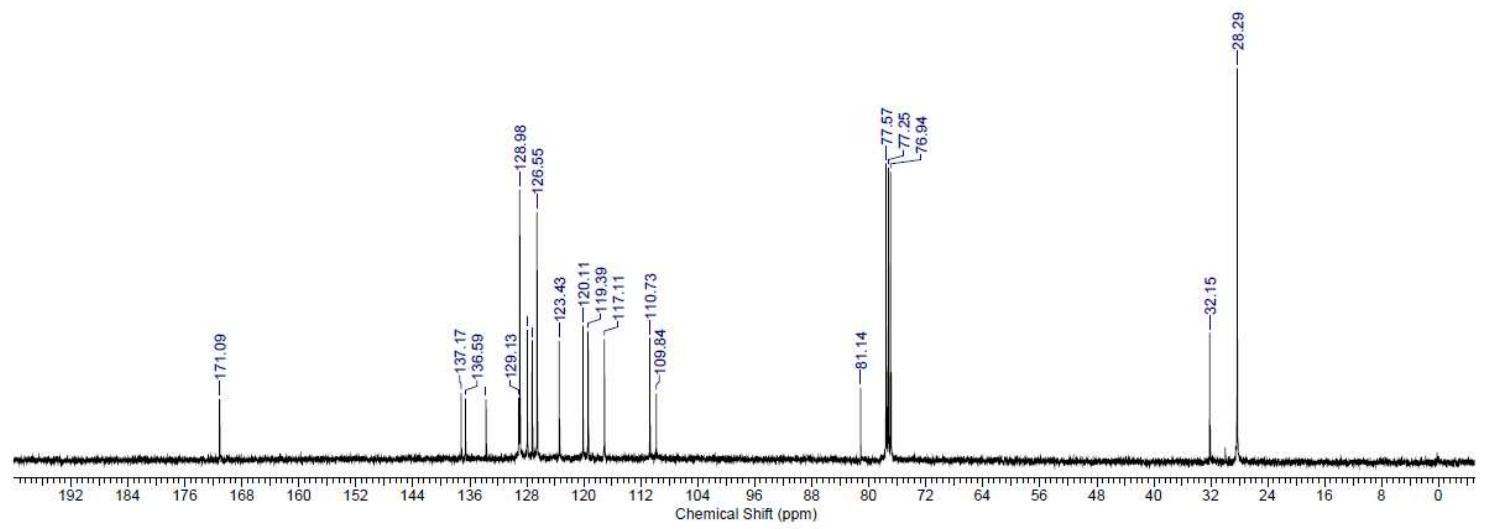


16. NMR Spectra of 1 ga

a) ${ }^{1} \mathrm{H}$ NMR Spectrum of 1 ga

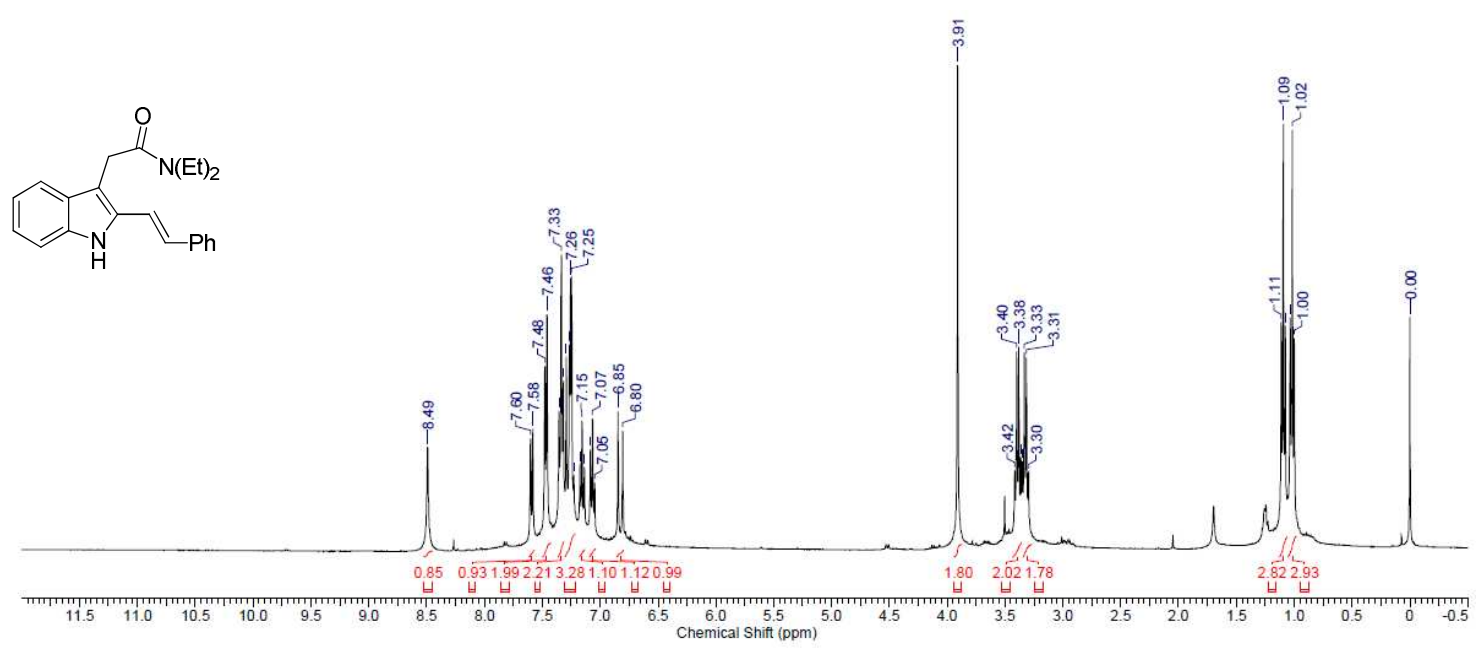

b) ${ }^{13} \mathrm{C}\left\{{ }^{1} \mathrm{H}\right\}$ NMR Spectrum of 1 ga

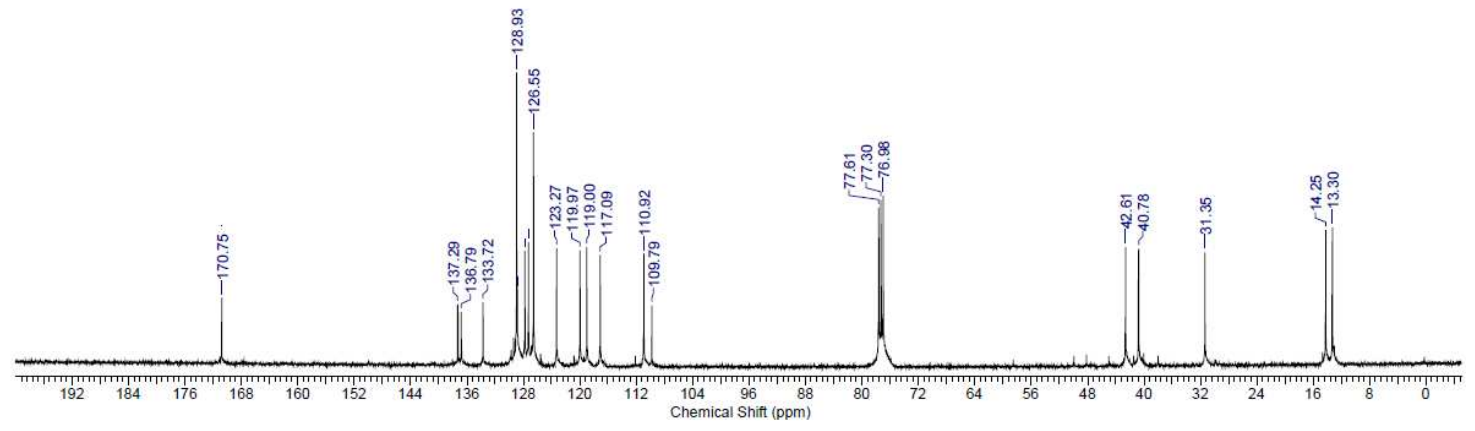


17. NMR Spectra of $\mathbf{1 h a}$

a) ${ }^{1}$ H NMR Spectrum of $\mathbf{1 h a}$

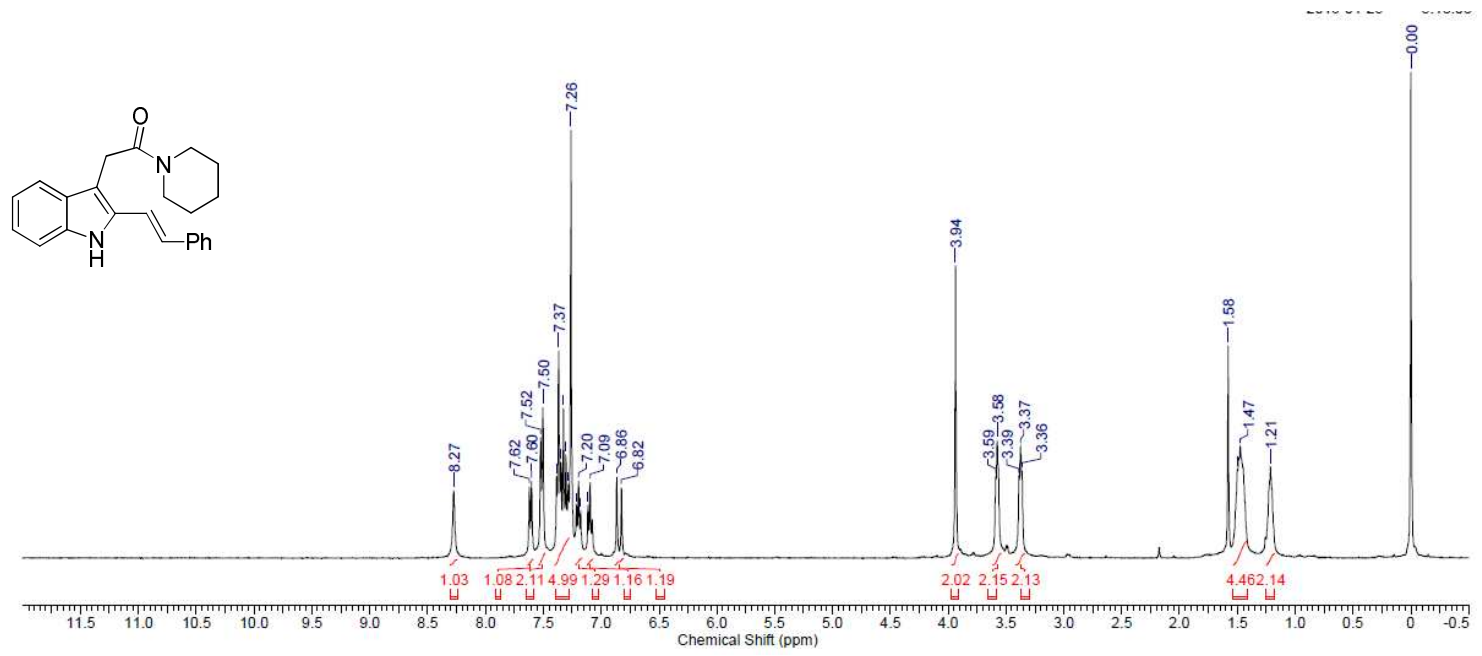

b) ${ }^{13} \mathrm{C}\left\{{ }^{1} \mathrm{H}\right\}$ NMR Spectrum of $\mathbf{1 h a}$

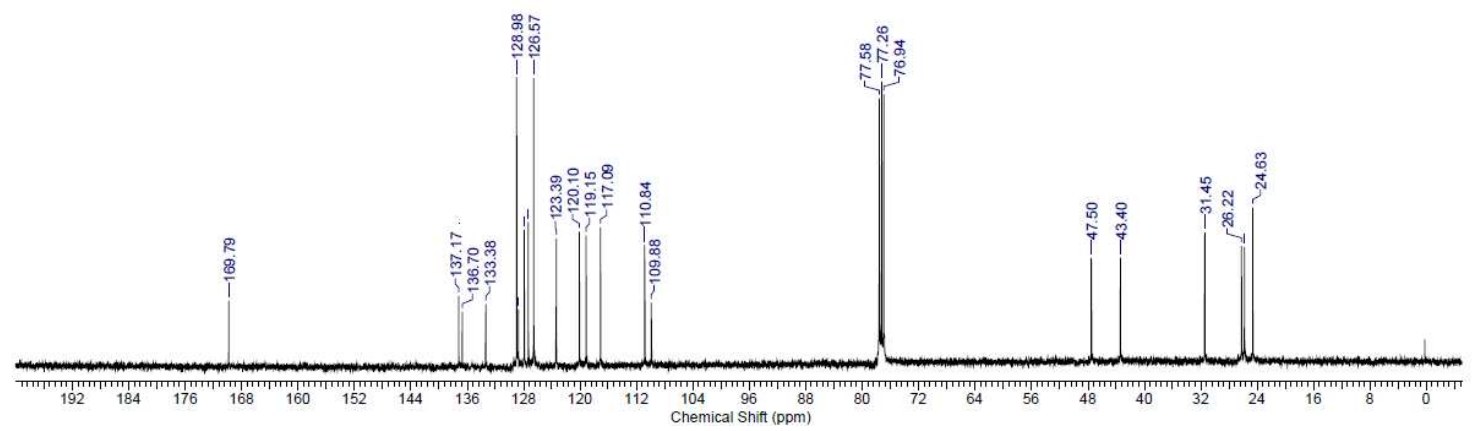




\section{NMR Spectra of $1 \mathbf{i a}$}

a) ${ }^{1} \mathrm{H}$ NMR Spectrum of $\mathbf{1 i a}$

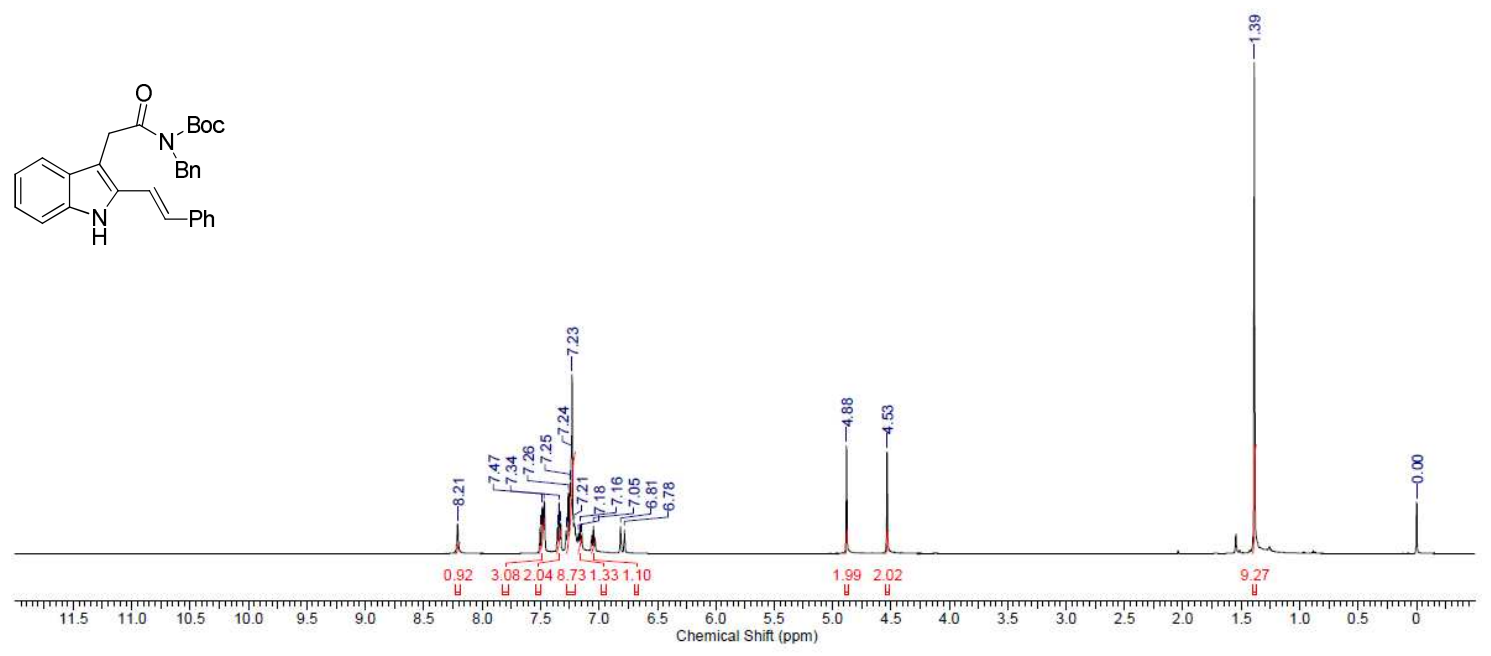

b) ${ }^{13} \mathrm{C}\left\{{ }^{1} \mathrm{H}\right\}$ NMR Spectrum of 1ia

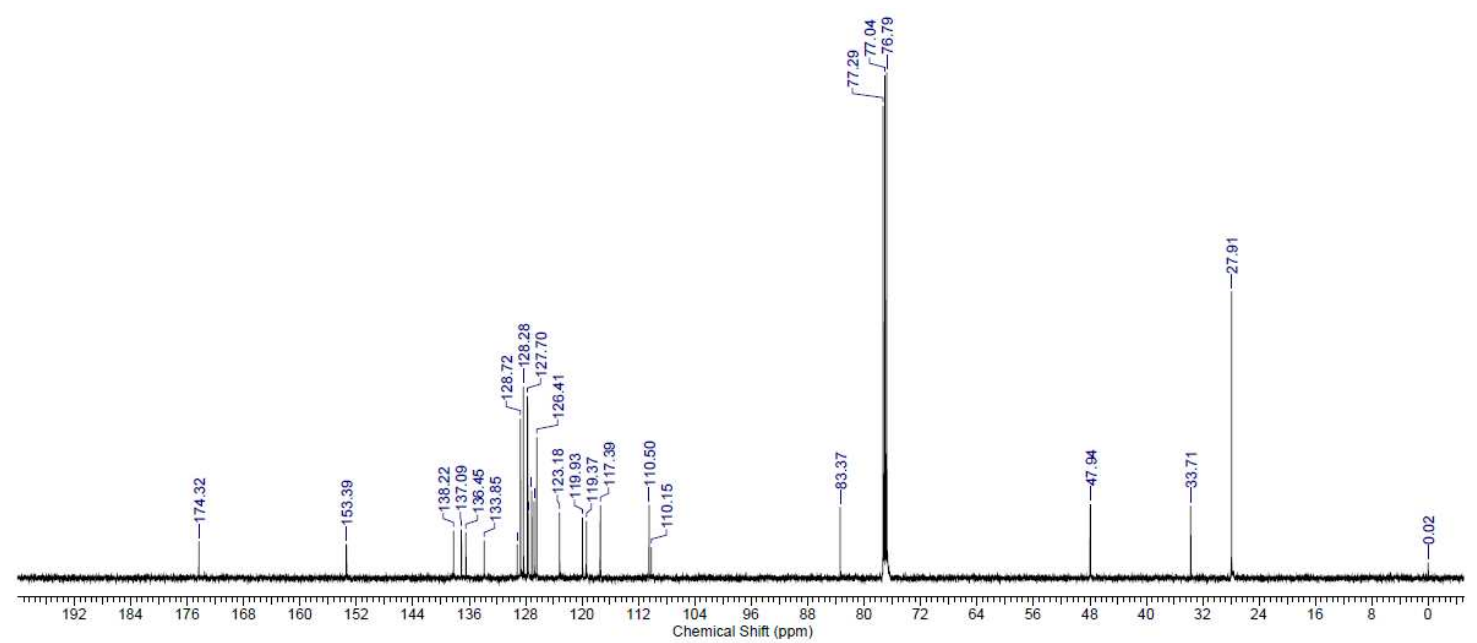


19. NMR Spectra of Compound $\mathbf{1 2}$

a) ${ }^{1} \mathrm{H}$ NMR Spectrum of $\mathbf{1 2}$

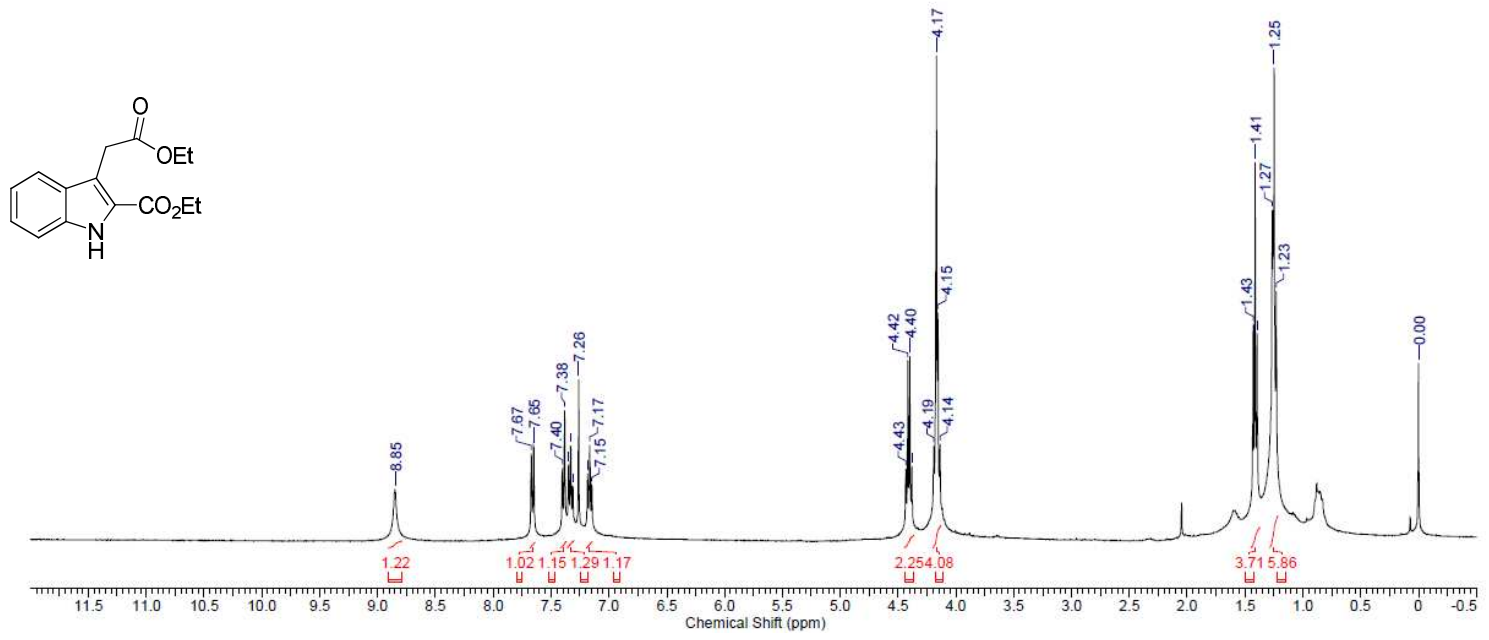


20. NMR Spectra of Compound 9

a) ${ }^{1} \mathrm{H}$ NMR Spectrum of 9

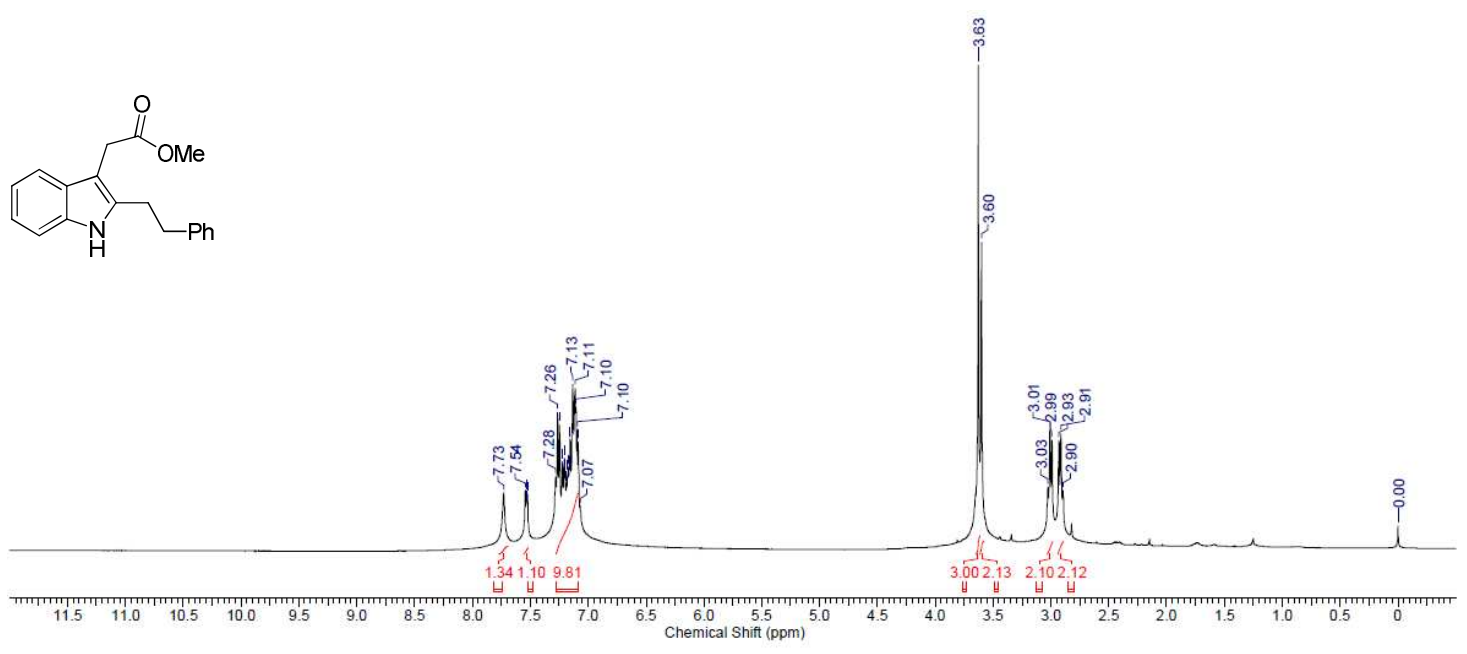

b) ${ }^{13} \mathrm{C}\left\{{ }^{1} \mathrm{H}\right\}$ NMR Spectrum of 9

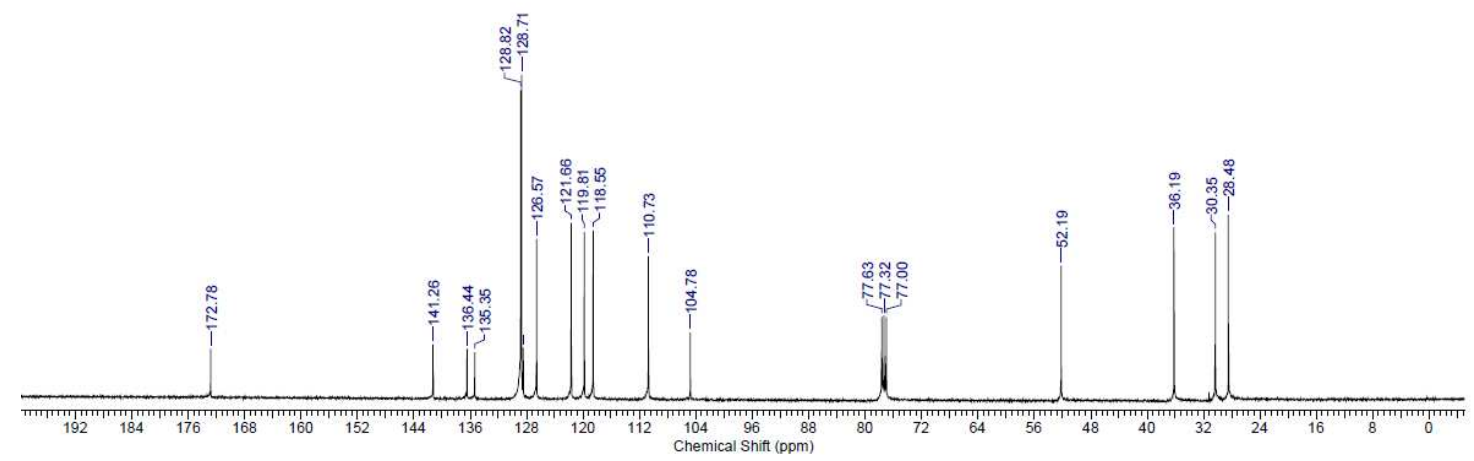


21. NMR Spectra of Compound $\mathbf{1 0}$

a) ${ }^{1} \mathrm{H}$ NMR Spectrum of $\mathbf{1 0}$

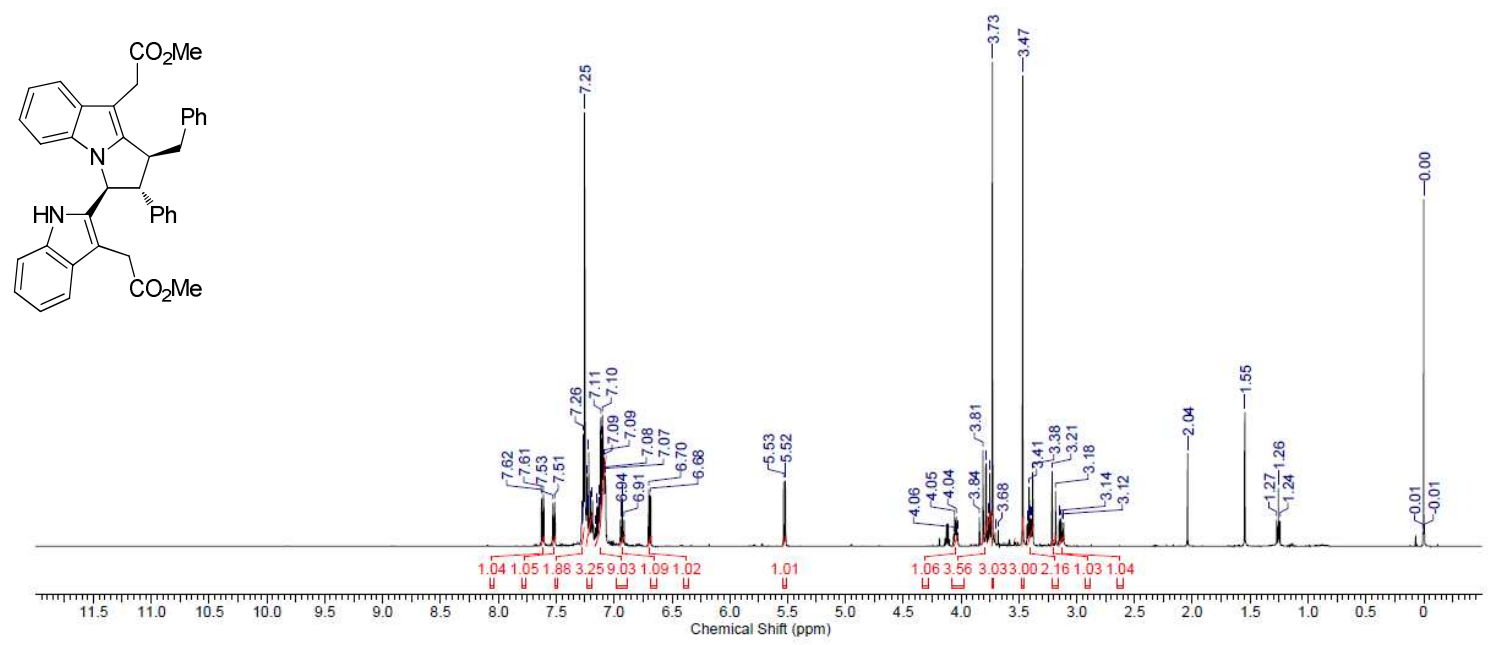

b) ${ }^{13} \mathrm{C}\left\{{ }^{1} \mathrm{H}\right\}$ NMR Spectrum of $\mathbf{1 0}$

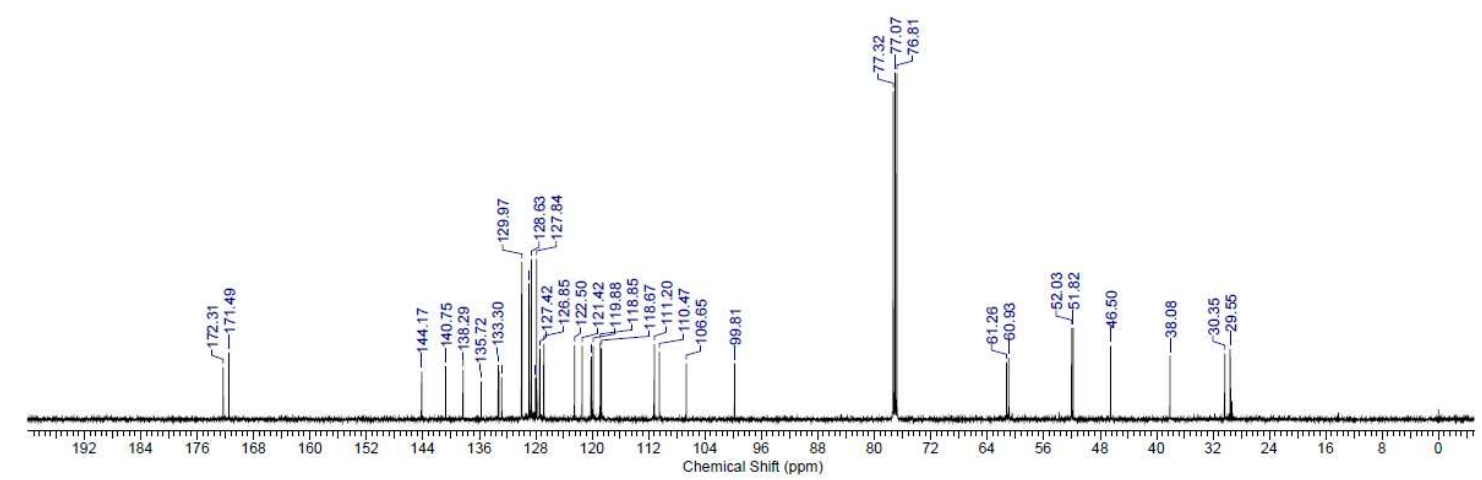

